Universidad

:

BIBLIOTECA

Document downloaded from the institutional repository of the University of Alcala: http://dspace.uah.es/

This is a postprint version of the following published document:

Kiefer, C.P., Del Río, P. \& Carrillo-Hermosilla, J. 2019, "Drivers and barriers of eco-innovation types for sustainable transitions, a quantitative perspective", Business Strategy and the Environment, vol. 28, no. 1, pp. 155-172.

Available at http://dx.doi.org/10.1002/bse.2246

This article may be used for non-commercial purposes in accordance with Wiley Terms and Conditions for Use of Self-Archived Versions

(C) 2019 Wiley

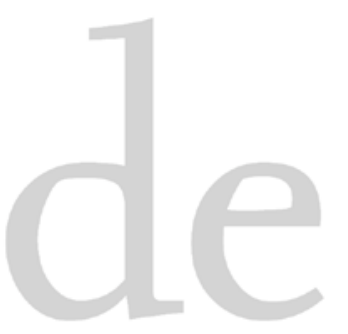

(Article begins on next page)

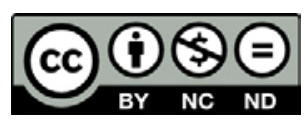

This work is licensed under a

Creative Commons Attribution-NonCommercial-NoDerivatives

4.0 International License. 
Final draft post-refereeing (Submitted 27 January 2018 - Submitted in revised form 8

September 2018 - Accepted 16 September 2018)

\title{
DRIVERS AND BARRIERS OF ECO-INNOVATION TYPES FOR SUSTAINABLE TRANSITIONS, A QUANTITATIVE PERSPECTIVE.
}

Kiefer, Christoph P.

Del Río, Pablo

Carrillo-Hermosilla, Javier
Consejo Superior de Investigaciones Científicas (CSIC)

christoph.kiefer@csic.es

Consejo Superior de Investigaciones Científicas (CSIC)

pablo.delrio@csic.es

Universidad de Alcalá (UAH)

javier.carrillo@uah.es

\begin{abstract}
Firms are influenced by internal factors (resources and capabilities) and external factors (e.g., regulation) when taking the decision to eco-innovate. However, the analysis of the internal factors has received much less attention than the external ones. This paper aims to fill this gap in the literature by analyzing the role of resources, competences and dynamic capabilities (RCCs) as determinants (drivers and barriers) of different eco-innovation (EI) types. Those EI types contribute differently to the sustainable transition of the economy and society, i.e., towards the Circular Economy. The statistical analyses reveal that RCCs are quite relevant as determinants of EIs and that different RCCs are more or less relevant for different EI types. In particular, the determinants of systemic and radical EIs substantially differ from those for continuous improvements. Our results suggest that physical RCCs, involvement in green supply chains, an EI-friendly corporate culture, technology-push and market-pull and internal financing resources represent drivers to these EIs, whereas cooperation, organizational learning, an ISO ecological certification and technological path dependency are barriers. The results may guide firms to pursue competitive and sustainable advantage by innovating through certain EI types corresponding to available and dedicated RCCs. They may also be useful to policy makers who are willing to promote specific EI types.
\end{abstract}

Key words: Eco-innovation; Drivers; Barriers; Sustainability Transition, Spain; small and medium-size enterprises; resource-based view; Circular Economy. 


\section{Introduction}

Eco-innovations (EIs), defined as innovations that reduce the environmental impact of consumption and production activities, would play a very relevant role in the quest for more competitive, environmentally and socially sustainable societies (Carrillo-Hermosilla et al., 2010; Machiba, 2010). Therefore, identifying their main determinants can help policy-makers to implement instruments which are effective and efficient to promote EIs and can support firms to create and sustain competitive advantage through EIs (Adams et al., 2012).

Substantial research on the drivers of EI has been carried out in the last two decades (see, e.g., De Medeiros et al., 2014; Del Río et al., 2016b; Díaz-García et al., 2015; Horbach et al., 2012, among others, for reviews of the literature). Although no single body of literature has succeeded in providing a comprehensive framework for the study of EI drivers (DíazLópez, 2008; Mazzanti and Zoboli, 2006), several theoretical approaches have proved to be relevant to guide the selection of explanatory variables, including environmental economics, the systems of innovation perspective and the resource-based view (RBV) of the firm (Del Río et al 2016b).

The combination of those approaches suggests that firms are influenced by internal (resources and capabilities) and external factors (e.g., public policy and stakeholder impacts) when taking the decision to eco-innovate. Despite recent efforts on the role of internal factors on eco-innovation, such as environmental management (Rehfeld et al., 2007; Rennings et al., 2006), equipment renewal (Cai and Zhou, 2014; Demirel and Kesidou, 2011), technological capabilities, internal R\&D (Kammerer, 2009; Rennings and Ziegler, 2004; Triguero et al., 2013), cooperation (Mazzanti and Zoboli, 2009), skilled personnel (Ghisetti et al., 2015; Marin et al., 2014) or organizational and managerial antecedents (Frondel et al., 2004; Triguero et al., 2013), research on their influence is still very limited, in sharp contrast to external determinants that have received much more attention. Furthermore, an allencompassing, comprehensive perspective on those internal factors is missing. In particular, the role of resources, competences and dynamic capabilities (RCCs) in driving EI has not been researched in a systematic manner, despite the fact that they are important drivers of business strategies and innovation performance. This may be due to two interrelated reasons: First, there is a theoretical reason why internal drivers to EI have received scant attention, at least until very recently. The initial literature on EI focused on the impact of regulation on the development and diffusion of EIs (see Del Río 2009 for a review). The neoclassical economics approach, usually adopted in those initial contributions, treats the firm as if it was a black box which reacts automatically to the external stimuli, whereas the role of the factors internal to the 
firm in driving EIs is mostly disregarded. In contrast, several streams of the literature (including industrial organization and corporate management) have shown that the firm is not a black box and that, in addition to their direct influence on EI, the internal variables mediate the relationship between the external drivers and the development and diffusion of EI. Second, there is a considerable difficulty to include these factors in existing research methods (including econometric models) due to poor data availability. As a consecuence, RCCs are often limited to the inclusion of only one variable in empirical studies with those methods. ${ }^{1}$ While useful, those analyses may not grasp the multifaceted influence of RCCs and their complex role in the EI process. Del Río et al. (2016a) provide a first attempt to analyze the role of RCCs as drivers of EI. However, the analysis is based on case studies and quantitative methods are not used. These authors hypothesize that, although all RCCs are relevant for the development and uptake of EIs, their relevance differs across EI dimensions.

On the other hand, different kinds of EIs contribute differently to sustainable transitions and the circular economy, but they all may have a role to play in this context (Braungart et al., 2007; OECD, 2009). While different types of EIs are likely to be driven by different factors (Del Río et al., 2017), the literature on the determinants of different EI types is tiny and focuses on process and product EIs (Rehfeld et al., 2007; Rennings et al., 2006). In contrast, fewer research efforts have been devoted to the analysis of the determinants of other EI types, with some exceptions (see 2.3).

This paper tries to fill these gaps in the literature. Its aim is to analyze the role of RCCs as determinants of different EI types with the help of a survey of 197 Spanish industrial SMEs.

Accordingly, the paper is structured as follows. The next section provides the theoretical framework and the links to the existing literature. The methodology is described in section 3 . The results of the analysis are provided and discussed in section 4 . Section 5 concludes.

\section{Theoretical framework and links to the existing literature.}

\subsection{Types of EI.}

\footnotetext{
${ }^{1}$ These variables include the adoption of an environmental management system (Horbach et al., 2012; Kesidou and Demirel, 2012; Rave et al., 2011), ownership of an approved ISO14001 or EMAS certification (Mazzanti and Zoboli, 2006), relevant changes in organizational structures (Horbach et al., 2012), technological capabilities proxied by R\&D (Belin et al., 2011; Horbach et al., 2012; Mazzanti and Zoboli, 2006) and employee qualification (Horbach et al., 2012).
} 
Different types of EI have been mentioned in the literature, including process vs. product EIs (Belin et al., 2011; Rave et al., 2011; Rehfeld et al., 2007; Rennings et al., 2006) and radical vs. incremental EIs (Del Río et al., 2017; Rave et al., 2011). A novel approach is provided by Carrillo-Hermosilla et al. (2010) and Kiefer et al. (2017) to identify different EI types by deriving the characteristics and dimensions of EIs. Kiefer et al. (2017) quantitatively explore the underlying structure of the EI concept based on the current knowledge of those characteristics and advance on the quantification of a four-dimensional framework proposed in the past by Carrillo-Hermosilla et al. (2010). They find that the identified characteristics shape an underlying structure of EIs along four dimensions (design, user, product-service and governance). The analysis identifies the factors which make up these dimensions, allowing a characterization of EIs. Kiefer et al. (2018) use these results to derive five EI types (Table 1), whose drivers will be analyzed in this paper. These EIs differ between each other in several respects, notably the degree of radicality.

\section{Table 1}

\subsection{Firm level antecedents: A Resource-based View perspective on EI.}

The theoretical framework on RCCs for EI builds on the integrated conceptual framework to analyze the impact of external and internal drivers on the development and adoption of EIs developed by Del Río et al. (2016a). This framework incorporates the impact of firm's RCCs and their interactions with external drivers on the development and adoption of EIs.

According to the RBV, the competitive advantage and innovation activities of firms strongly depend on their valuable, inimitable and non-substitutable resources or capabilities, located within the organization (Russo and Fouts, 1997). Three main concepts are used by this approach (Cohendet and Llerena, 1998; Katkalo et al., 2010):

- Resources are firm-specific assets whose value is context dependent. They can be tangible (financial reserves and physical resources) or intangible (reputation, organizational culture, technology, customer relationships and human resources).

- Competences (or capabilities) are resources which result from activities that are performed repetitively in a firm. Organizational competences are usually underpinned by organizational processes or routines (Dosi et al., 2000; Nelson and Winter, 1982). 
- Dynamic capabilities are the capacities of an organization to purposefully create, extend and modify its resource and competence base (Helfat et al., 2007) to both address and shape rapidly changing business environments (Teece et al., 1997).

The RBV has proven to be particularly useful in the analysis of the EI determinants (Cainelli et al., 2015; Kabongo and Boiral, 2017). According to the RBV, firms are heterogeneous with respect to their endowments of resources/capabilities, which are accumulated over time (Markard and Worch, 2010) and sticky, at least in the short-term (Hart, 1995; Teece et al., 1997). In this paper, RCCs are those controlled by the firm, which fundamentally enable it to eco-innovate. Some are created/accumulated, while others are acquired or accessed from other organizations, through collaboration or networking (Markard and Worch, 2010). "Innovation intermediaries" can assist firms to get some of these resources from external sources. Kanda et al. (2015) develop an approach for analysing the functions of intermediaries in eco-innovation. Their empirical analysis shows that the functions of the innovation intermediaries are particularly relevant for the overall goals of an innovation system. The authors suggest that eight important functions of innovation intermediaries can overcome the "unavailability" of certain firm RCCs for eco-innovation. Similarly, Polzin et al. (2016) address "the complex set of barriers surrounding (eco-)innovation (...), with an emphasis on the mobilization of finance" (op.cit., p. 35). They explore the role of institutional innovation intermediaries in accelerating the commercialisation of (clean) technologies, with a focus on private financial resource mobilization. The authors show that financial barriers to eco-innovation can be partly overcome by particular functions of institutional innovation intermediaries which, in turn mobilise private finance along the innovation process.

Our literature review on the RBV suggests that six broad groups of RCCs are relevant for EI: physical, reputational/cooperational, motivational/organizational, financial, human capital and technological (see details on how this literature review was performed in section 3.1). Their influence on EI is discussed in Table $2^{2}$. In practice, firm RCCs may be interrelated and belong to several groups e.g., certain physical RCCs are frequently tied to financial RCCs (i.e., Penrose, 1959). As recognized by the RBV itself, these RCCs are not isolated from each other. On the contrary, they may interact between each other in complex ways, both in a synergistic and conflicting manner.

\footnotetext{
${ }^{2}$ Note that we follow the RBV for the categorization of 6 groups of RCCs. This is not the only possible way to categorize the different types of RCCs, however.
} 


\section{Table 2}

\subsection{RCCs as determinants of different EI types.}

This paper focuses on RCCs as determinants of EIs with different degrees of radicality (e.g., systemic and radical EIs vs. incremental ones). In general, since the degree of radicality, disruption, complexity and systemicness can be expected to be higher for systemic and radical than for incremental EIs, the amount of funds, internal innovation capabilities and degree of cooperation with external actors required to develop or adopt systemic and radical EIs would also be greater (Del Río et al., 2017; Rave et al., 2011). In contrast to incremental EIs, both radical and systemic EIs imply a substantial change with respect to existing EIs and this is the reason that they are grouped together when proposing the hypotheses. However, they differ on whether such departure with respect to incremental EIs is micro-level (radical EIs) or systemlevel (systemic EIs) and this may lead to differences among them regarding the impact of different RCCs.

EIs, especially of the systemic and radical type, may lead to drastic changes in the physical base of the company. They could render this base obsolete. A highly capitalintensive base, which entails a high replacement cost, can be a significant barrier for systemic changes (Khanna et al., 2009). Therefore, the following hypothesis is proposed: Hypothesis 1. Existing physical RCCs represent a stronger barrier to systemic and radical EIs than for other EI types.

Several contributions to the eco-innovation literature empirically show that EIs, especially of the systemic type, necessarily involve cooperation between multiple stakeholders, including research centres, universities, consumers, competitors, suppliers and governments, sometimes even more than general innovations (Belin et al., 2011; Cainelli et al., 2011; De Marchi, 2012; Del Río et al., 2017, 2016a; Halme and Korpela, 2014; Kanda et al., 2016). Using a case-study methodology, Del Río et al. (2016a) show that systemic changes usually involve changes in the supply chain and lead firms to collaborate with other stakeholders. They emphasize the important role of networking and the capacity for stakeholder integration. Similarly, Wagner and Llerena (2011) find out that capacity for stakeholder integration plays an important role in eco-innovation. The econometric analysis in del Río et al. (2017) indicates that involvement in external knowledge flows and cooperation is a crucial variable for small firms to eco-innovate in systemic and radical eco-innovations 
versus incremental ones. In line, Halme and Korpela (2014) find that cooperation is a necessary RCC for eco-innovations in resource-contrained SMEs. Kanda et al. (2016) show that regulation, public-private partnerships, and legitimacy are particularly important in the diffusion of large-scale environmental technology systems. In particular, they show how cooperation between multiple stakeholders, including consumers and citizens, is necessary for the development of systemic and radical EIs. Belin et al. (2011) show that, since EI is often characterized by relatively new technologies, it requires more external sources of knowledge and information than innovation in general. Cainelli et al. (2011) also show that networking and cooperation with universities is key for achieving more radical eco-innovations. The empirical analyses in De Marchi (2012) suggest that eco-innovations require more cooperation than other innovations, given their systemic and complex character and that ecoinnovators have to leverage on the competences of external partners to a higher extent than other innovators.

EIs which change the value proposition of the firm may require changes in the physical structure of a firm (Khanna et al., 2009; Teece and Pisano, 1994). More systemic EIs may lead to a greater need for changes in the infrastructure of existing value chains or to the creation of new value chains (Andersen, 2002). The reputational and cooperational capabilities are relevant in this context (Bocken et al., 2014; Ghisetti et al., 2013). Systemic EIs can lead to substantial changes in value chains and in other established networks (Bocken et al., 2014; Ghisetti et al., 2013).

Hypothesis 2. Systemic and radical EIs are more cooperation-intensive than other EI types.

Corporate reputation influences the dynamic capability to create new networks or to be involved in them (Van Kleef and Roome, 2007). The corporate culture, the strategic approach to innovation and the orientation towards the future are related to different EI types (Rennings, 2000). Systemic EIs require a corporate culture which facilitates changes in the firm (Horbach et al., 2012; Rehfeld et al., 2007). Furthermore, the success of systemic EIs depends on the involvement of potential users and clients (Brío et al., 2006; Junquera et al., 2012). Corporate culture (regarding the orientation towards learning, exploration/experimentation and risk taking) and the role of senior management (the use of corporate tools to reach the company's objectives) guide individuals in eco-innovative processes and promote systemic EIs (Hillary, 2004; Horbach and Jabob, 2018). Hypothesis 3. Systemic and radical EIs require an environmentally and innovation-oriented business culture to a greater extent than other EI types. 
The cost of EI processes is high, particularly for systemic EIs. Radical and systemic EIs usually require large up-front investments and, thus, substantial financial resources are needed. Access to financing (at reasonable costs) is important for firms in order to engage in these processes (Brown et al., 2012). Within these, internal financial resources are more likely to be drivers of EI with respect to external financing. External financing can be more expensive and/or require compliance with performance indicators for the EI processes themselves, which may inhibit experimentation and risk taking (Andersson and Lööf, 2011). The previous literature notes that both are relevant antecedents for systemic eco-innovations (Andersson and Lööf, 2011; Brown et al., 2012).

Hypothesis 4. The availability of internal financial resources is a stronger driver for systemic and radical EIs compared to other EI types.

Rave et al. (2011) show that more radical EIs typically require more fundamental and often collaborative R\&D activities. In contrast, demand-pull factors would lead to more incremental than radical EIs (Belin et al., 2011; Horbach, 2008). Knowledge is crucial for the development and adoption of highly-novel EIs (Horbach, 2008; Jové-Llopis and SegarraBlasco, 2018; Yang et al., 2014). The availability of knowledge and the continuous provision of new knowledge is required (Cohen and Levinthal, 1990; Teece and Pisano, 1994). The active management of knowledge (dynamic capability) leads to a higher innovation performance (López-Nicolás and Meroño-Cerdán, 2011). This is specially the case regarding systemic and radical innovations (Yang et al., 2014).

Hypothesis 5. Systemic and radical EIs require stronger internal innovation capabilities (human intellectual RCCs) compared to other EI types.

Finally, it is important to take into account that systemic changes rest on new technology (Horbach, 2008) and, thus, established technological systems can be a substantial barrier to systemic and radical EIs (Könnölä et al., 2006).

Hypothesis 6. Systemic and radical EIs are less dependent on existing technological RCCs than other EI types.

\section{Materials and methods}




\subsection{Definition of input variables}

A literature review based on several databases (EBSCO, ScienceDirect, Web of Science (ISI), JSTOR, Wiley Online, Scopus and Springer Link) was conducted in order to identify contributions in the contexts of the RBV and EIs. RCCs in the proposed and generally accepted groups of RCCs (Barney, 1991; Grant, 1991), that have been studied in the past and in the context of EI, were identified. 219 contributions describing firm antecedents (drivers and barriers) were used for item generation. They were grouped along the proposed 6 categories of RCCs.

For the subsequent quantification, each RCC was associated with a quantifiable variable. Table 3 describes the different RCCs used in the analysis.

\section{Table 3}

Since the variables to quantify the RCCs in Table 3 are not comprehensively included in any secondary dataset, and information about EIs should also be included for the analyses proposed in this article, a survey had to be carried out. This was done following a deductive scale development process (Fields, 2002; Nunnally, 1978).

The definitions of constructs identified in the previous literature guided the generation of items for the questionnaire. For new items, content adequacy was assessed. Therefore, the questionnaire was tested with 11 experts, who were chosen among academics and business managers ${ }^{3}$. Comments and feedback helped to formulate the questions more precisely and ensured a clear understanding.

\subsection{Target universe and data gathering}

This study is targeted at Spanish industrial SMEs. The industrial sector is very relevant in the transition towards sustainable production and consumption patterns given its weight in the economy and its high historic and current environmental impacts (IEA, 2015). Industry is an innovative and eco-innovative sector (OECD, 2009). SMEs, which are those firms with more than 50 and less than 250 employees (European Commission, 2017), are important for eco-innovation, given that $99 \%$ of all European firms are SMEs and that $2 / 3$ of private employment is generated by SMEs. They show unique characteristics, such as high flexibility, lean structures and informal communication patterns (Halme and Korpela, 2014; Keskin et al.,

\footnotetext{
${ }^{3}$ The list of experts is available from the authors upon request.
} 
2013). Finally, Spain has some unique features which influence the development and update of EIs (Del Río et al., 2017) and which make this case worth analyzing. ${ }^{4}$

According to the Iberian Balance Sheet Analysis System (SABI), 2821 firms had those features in 2014. Questionnaires were targeted at personnel close to innovation areas. The identification of the direct contact data of such personnel was professionally undertaken by a market-research company. All identified persons were then invited to complete the questionnaire via email (between May and June 2014). 638 persons were accessed, 430 completed the questionnaire and 197 firms developed or adopted an EI in the observed period. This represents a response rate of $29 \%$, which is satisfactory compared to similar studies (Horbach et al., 2012; Kesidou and Demirel, 2012). Tables 4 and 5 provide further details on the procedure and the sample.

\section{Table 4}

\section{Table 5}

\subsection{Statistical techniques}

EIs have been comprehensively characterized by Kiefer et al. $(2017,2018)$. This article uses their 20 characteristics or subdimensions of EIs as well as their taxonomy of five eco-innovation types (see 2.1).

Regarding the measurement of RCCs for EI, Exploratory Factor Analyses (EFA) have been undertaken. They detect underlying structures to empirical observations and reduce a large number of individual variables to a smaller set of factors with similar information. In EFA, no presumption on variable behavior has to be made. The solution of principal components (PCA) is the most common and generally preferred alternative in EFA (Di Stefano et al., 2012). A similar procedure has been followed in other EI studies (Cai and Zhou, 2014; Castellacci and Lie, 2017; Sáez-Martínez et al., 2016). The EFA was carried out in two steps. In an initial analysis, we investigated the optimum amount of factors which should be kept and, then, the definitive analyses were undertaken. An oblique rotation type

\footnotetext{
${ }^{4}$ These features, which are shared with other Southern European countries, include a weaker national innovation system (OECD, 2012), a lower rigor in applying ecological regulations (Blanke and Chiesa, 2013; Johnstone et al., 2010) and a lower willingness to pay "green" price premiums by consumers (European Commission, 2011).
} 
was deemed most adequate ("direct oblimin") to identify the relationship between factors. The results of this step led to a set of RCCs for EI. The relations between firm-level RCCs and the different EI types were identified in a second step through regression analyses.

The aim was to model the relation between the EIs and the RCCs (results of EFA). This resulted in a categorical dependent variable, continuous-scale independent variables as covariates (the factor scores) and binary, nominal and ordinal independent variables as factors. In such cases, applying Multinomial Logistic Regression (MNLR) is deemed adequate (Field, 2013) and the MNLR could be expressed as (Castellacci and Lie, 2017):

$$
\begin{gathered}
\operatorname{Pr}\left\{Y_{i}=j\right\}=\frac{\exp \left(\beta_{j}^{\mathrm{T}} X_{i}\right)}{1+\sum_{k} \exp \left(\beta_{\mathrm{k}}^{\mathrm{T}} \mathrm{X}_{\mathrm{i}}\right)} \quad \text { where } \mathrm{j}=2,3, \ldots, \mathrm{J} \\
\operatorname{Pr}\left\{Y_{\mathrm{i}}=1\right\}=\frac{1}{1+\sum_{\mathrm{k}} \exp \left(\beta_{\mathrm{k}}^{\mathrm{T}} \mathrm{X}_{\mathrm{i}}\right)} \quad \text { where } \mathrm{j}=1
\end{gathered}
$$

Where $Y_{i}$ are the set of $j$ clusters, $X_{i}$ refers to the vector of independent variables and $\beta_{j}^{T}$ is the vector of the estimated coefficients which are specific to each group $\mathrm{j}$. The two expressions are nonlinear and require an iterative solution based on the Maximum Likelihood parametric estimation procedure. A parameter is estimated with a distribution that maximizes the plausibility of the realization of the observed data. The Newton method usually finds such a solution with a low number of iterations (Castellacci and Lie, 2017).

\section{Results and discussion.}

\subsection{Resources, competencies and dynamic capabilities (RCCs).}

While the literature review suggested the existence of many RCCs (see preceding sections), the aim was to reduce the number of individual variables to a smaller number by applying EFA. In the initial analyses, all variables that belong to a group of antecedents (drivers/barriers) have been included and the Eigenvalues of each variable have been obtained. The correlation matrix allows the identification of non-significant or atypically high correlations. The communalities of the variables, the reproduced variance by each extracted factor and the component matrix of the initial solution have been analyzed. In case the initial analyses for a group of drivers/barriers led to low correlations, low communalities and low variance, we have not proceeded further with the EFA. This means that the variables of this group of drivers/barriers can't be reduced to a lower number of factors, since they accurately 
represent such group of drivers/barriers. Additionally, if an individual variable presents "complex structures" (very high loads in more than one factor), it has been separated from the definitive analysis and kept individually. Based on this analysis, a decision on the optimal number of factors to retain in each group of drivers/barriers has been taken.

The sampling adequacy of the variables finally included in the definitive factor analyses has been studied with Bartlett's Test of Sphericity, partial correlations in the antiimage matrix, the measures of sampling adequacy of each particular variable (MSA) and the measure of the global sampling adequacy of Kaiser-Meyer-Olkin (KMO).

In addition, construct validity and reliability have been assessed (Fields, 2002; Nunnally, 1978). Construct validity has been evaluated by means of factor loadings, which in all cases have exceeded the minimum value of 0.40 , suggesting construct convergent validity. The absence of cross-loadings indicates construct discriminant validity. Scale reliability has been assessed with Cronbach's Alpha. The cut-off value of 0.60 recommended by Nunnally (1967) has been exceeded without exceptions. ${ }^{5}$ The results of the EFA for each RCC are summarized in Table 6. 28 drivers and barriers in 6 groups of RCCs have been identified from the previous literature and from the analysis carried out in this paper.

\section{Table 6}

\subsection{Relating RCCs and EI types.}

In the MNLR analyses, the Model Fitting Information, the Goodness-of-Fit and the level of correspondence between predicted and real values are assessed with the R-statistic. However, since the multiple regression coefficient $\mathrm{R}^{2}$ / ordinary least squares (OLS) cannot be calculated, the likelihood ratio or pseudo- $\mathrm{R}^{2}$ (Field, 2013) for MNLR has been calculated. Specifically, the Model Fitting Information compares two models: the prediction of the dependent variable with a simple constant calculated as the average of all independent variables (baseline model) and the model of the specific effects of each independent variable (final model).

First, the fit of the model is evaluated. Specifically, the value "-2 Log Likelihood", or 2LL, which indicates the amount of unexplained information after adjustment of the two models (Field, 2013) is calculated. The value drops considerably from 535,850 to 209,025, indicating a better fit of the final model compared to the baseline model. The chi-square test

\footnotetext{
${ }^{5}$ The tables with the correlation matrixes and the factor loadings have not been included in this paper for reasons of space, but they are available from the authors upon request.
} 
of the final model is 326,825 . Because the test is significant $(p=0,000)$, the final model explains a substantial amount of the original observed variability, i.e. it has a better fit than the baseline model.

The Akaike Information Criterion (AIC), which is an indicator of the "relative quality" of statistical models, is calculated. A lower AIC value indicates that the model is more appropriate for use (Field, 2013). The AIC value drops from 543,850 to 465,025 indicating that the final model is preferred over the baseline model. However, the Bayesian Information Criterion (BIC) does not decrease in the same way. This is acceptable because of the different objectives of such criteria: While the BIC's objective is to show the "true model", the AIC aims to find the "better prediction" (Kuha, 2004).

The results show that the final model has a better fit than the baseline model and, thus, it is more capable to explain the real, observed values.

In a second step, the Goodness-of-Fit is assessed. Both the Pearson and Deviance statistics evaluate whether the values predicted by the final model are significantly different from the observed values (Field, 2013). Significance is not given ( $p=1,000$ in both cases). Therefore, the model predicts the observed values sufficiently well. This confirms the goodness of the adjustment. The values of the R-statistic calculated according to Cox and Snell's and Nagelkerke's method vary between 0 and 1 . Both values are high. The final model predicts $86.7 \%\left(\mathrm{R}_{\mathrm{N}}^{2}\right)$ of the observed variance in the dependent variable. Thus, the model is very well suited to relate the type of EI to firm-level antecedents.

After evaluating the model itself and concluding on its adequacy for this analysis, the individual predictors within the model are evaluated. First, we have checked which of them contribute significantly to the global model. Table 7 summarizes the results of each of the five EI types for each RCC. MNLR requires a reference category, against which all other categories are contrasted (Field, 2013; Hair et al., 2010). “Continuous improvement EI” was chosen as the reference category, because the other types of EI are conceptually expected to differ from this category. For reasons of space, only the p-value (Sig.) and the $\operatorname{Exp}(\mathrm{B})$ (or Odds ratio, OR) are provided. ${ }^{6}$ The OR indicates how the probability ratio of developing/adopting a specific EI type increases or decreases with respect to the reference EI

\footnotetext{
${ }^{6}$ The values of $B$, the standard errors, the Wald test and the lower and upper bounds for the OR at the $95 \%$ confidence level are not included here for reasons of space. They can be provided by the authors upon request.
} 
when a specific determinant increases (by one unit). ${ }^{7}$ An OR higher (lower) than 1 indicates that the determinant is a driver (barrier) compared to the reference EI.

\section{Table 7}

The comparative results of the MNLR between the drivers and barriers for the baseline of continuous improvement EIs and for the other EI types show the existence of clear differences. Among the drivers/barriers for all types, there are some similarities between radical and systemic EIs on the one hand, and continuous improvement and eco-efficient EIs on the other, which confirms the suitability of combining them together in the hypotheses. Also, the MNLR does not identify any differences in the drivers and barriers for the baseline and externally-driven EIs.

Regarding the physical RCCs, the results show that the drivers are similar for systemic and radical EIs and different to other EI types. There aren't any differential drivers of externally-driven EIs with respect to the reference category and this is also the case for ecoefficient EIs. The perceived physical slack is a particularly relevant driver of systemic EIs, i.e., a higher (perceived) unavailability of physical resources increases the probability of carrying out systemic and radical EI types compared to the reference case. Therefore, the absence of an installed base is a driver of systemic/radical EIs, which are more likely to require new physical resources. In contrast, the physical slack of non-durable physical RCCs suggests the opposite: the existence of those RCCs, typically used and consumed in the processes of experimentation (Geiger and Makri, 2006; Nohria and Gulati, 1997, 1996), is a driver of systemic and radical EIs.

The "novelty of physical RCCs" is a driver of radical EIs. This is a logical result since these EIs are the result of a push from science and technological innovation. Thus, the newer the physical resources (which include those used for experimentation of new technologies such as laboratories), the more likely that technology-push EIs will be developed and adopted. The probability to introduce an EI of this type decreases with the age of the physical resources. On the contrary, the age of the RCCs is not a driver of systemic EIs. In contrast to radical EIs, systemic EIs entail an institutional change (cooperation, supply chains). Being involved in value chains, networks and cooperative innovation implies complementarity of the individual firms' existing physical RCCs with those provided by others. This reduces the

\footnotetext{
${ }^{7}$ For example, the OR of 11.015 for the "Perceived physical slack" of systemic EIs (3rd column, 4th row) indicates that an increase in the perceived physical slack increases the probability of developing/adopting a systemic EI with respect to developing/adopting a continuous improvement EI by 11.015, i.e., by 11 times.
} 
relevance of this firm-level RCC (Adams et al., 2012; De Marchi, 2012). Additionally, established and "older" firms tend to be more and more prolongedly engaged in networking and cooperations, which in itself is a driver to systemic EIs (Cainelli et al., 2011). Therefore, the age of the installed base is likely to be less influential to this type of EI.

The influence of the installed base on the other EIs (with respect to the reference type) is either non-existent (externally-driven EIs) or very limited (eco-efficient EIs). The perceived low availability of physical resources encourages eco-efficient EIs, i.e. motivates firms to improve the eco-efficiency of products and processes with the existing physical resources. Eco-efficient EIs, which are the result of business-as-usual activities, are unlikely to require new physical RCCs, since they are incremental EIs with a "drop-in" characteristic, i.e., they can be easily fitted into the existing technological and infrastructural system (Kemp, 1994).

To sum up, our research suggests an ambiguous relationship between the installed base (physical RCCs) and systemic/radical EIs and an influence of the age of such installed base on radical EIs. Therefore, hypothesis 1 cannot be rejected.

Regarding the reputational and cooperational RCCs, our results show that cooperation reduces the probability of developing/adopting all types of EI with respect to the reference EI. This result is surprising regarding the systemic and radical EIs which, according to the literature, require substantial cooperation with different types of stakeholders (see 2.3). A closer look at the data reveals that the average value of firms which carry out this type of EI cooperate with three different types of firms and institutions ("types" refers here to each classification, i.e. "universities", "regulators", etc.). Cooperating with two of these entails a high score for importance. Since the target universe in our study is made up of SMEs with restricted RCCs, an increase in the number of types of cooperation partners may entail a considerable burden for the firm and lead to coordination problems due to lack of internal RCCs. Internal conflicts and inefficiencies in the management of cooperation may arise.

On the other hand, our results confirm the importance of involvement in "green supply" chains as an EI driver (Simpson et al., 2007; Testa and Iraldo, 2010). It is not only a driver of the systemic and radical EIs but also of the eco-efficient ones. This suggests the relevance of factors upstream the value chain as a driver of these types of EIs. Several authors (Azevedo et al., 2011; Vachon and Klassen, 2006) find that cooperation with suppliers is a driver of systemic EIs. Other reputation and cooperation RCCs do not influence the different EI types compared to the reference EI. Therefore, hypothesis 2 can (partly) be rejected.

Concerning the motivational and organizational RCCs, technology-push and marketpull seem to discourage systemic/radical EIs with respect to the reference EI. Although 
unexpected, this result merits close attention. The small OR and relatively high Standard Errors suggest "complete separation", which occurs when a dependent variable can be perfectly predicted by the independent variable in a MNLR ${ }^{8}$ : all types of motivations (techpush, market-pull, a mixture of both and additionally firm-specific motivations for systemic EIs) predict the realization of these two types of EIs compared to the reference EI. Continuous improvement EIs are the result of the daily operations of the firm (i.e. without a specific motivation). In contrast, any specific motivation leads to higher probabilities of introducing systemic/radical EIs.

ISO or EMAS ecological certifications do not encourage systemic/radical EIs compared to the reference one. This is an expected outcome and it is in line with previous literature. For example, Könnölä and Unruh (2007) find that ecological certifications would hinder systemic/radical EIs due to lock-in effects. ISO or EMAS ecological certifications do not encourage eco-efficient EIs either. The reason is that, conceptually, the reference category of continuous improvement EI and eco-efficient EI do not differ significantly in this respect. In fact, Kiefer et al. (2018) show that both EIs are conceptually close. In both cases, the EIs arise without a specific environmental motivation and the ecological benefit may be an unintended side effect.

On the other hand, our results reveal the importance of an EI-friendly corporate culture, particularly for systemic and radical EIs. This is an expected result. Given the intrafirm changes that these EIs entail, a high top-level management commitment can be crucial for the development/adoption of these EIs. In contrast, continuous improvement EIs are the outcome of business-as-usual activities in the firm and show high compatibility with the established system. Conceptually, future orientation is not related to eco-efficient EIs, as these tend to be focused on the short and medium terms. Thus, a higher sustainability orientation would lead to a higher probability of implementing systemic EIs. Therefore, hypothesis 3 cannot be rejected.

Regarding the financial RCCs, our results confirm the relevance of internal financial sources as a driver of systemic and radical EIs compared to external financing. The preference of SMEs for internal financing may facilitate more risky eco-innovation processes which lead to more radical EIs. According to our results, higher liquidity ratios (or current ratios) reduce the probability to develop/adopt a radical $\mathrm{EI}^{9}$. They are usually indicators for short-term

\footnotetext{
${ }^{8}$ Statistically, the probability curve between the predictor and result cannot be found, because infinite possibilities exist (Field, 2013).

${ }^{9}$ The current ratio is a liquidity ratio that measures a company's ability to pay short-term obligations. To gauge this ability, the current ratio considers the current total assets of a company (both liquid and illiquid) relative to
} 
oriented and highly volatile businesses, i.e. high risks of finance shocks (Brown et al., 2012). Short-term oriented business may focus on efficiency-related innovative activities (Wu et al., 2015). On the other hand, high risks lead to hesitation towards significant changes (OECD/Eurostat, 2005). Additionally, high available liquidity may result in suboptimal levels of EI due to relaxed controls (Marlin and Geiger, 2015). Also, previous research has shown that high liquidity levels may be an indicator for financially constrained firms (Brown et al., 2012), which discourages potential eco-innovators from undertaking radical EIs. Similarly, we find that the higher the profitability of capital, the lower the probability to engage in systemic/radical EIs. Systemic/radical EIs would require a higher financial muscle by the companies. On the other hand, consolidated businesses tend to have higher profitabilities of capital, i.e., compared to new firms. Yet, their past trajectories frequently act as barriers to more radical and systemic EIs as a result of lock-in in past success (Unruh, 2000). These results are in line with i.e., Perez (2011), who suggests that financial capital can both hinder and drive technological development. As financial capital to some extent is part of existing 'paradigms' it may hinder development and diffusion of novel technologies. On the other hand, Karltorp et al. (2017) argue that financial capital can be flexible and is not locked-in to a certain technical configuration and can therefore drive technological innovation and radical change. Finally, the greater the financial restrictions (financial slack), the greater the probability to develop/adopt eco-efficient EIs, since these EIs lead to an immediate profit for the company through a reduction in the costs. This is very attractive, especially for firms with financial restrictions. Therefore, hypothesis 4 cannot be rejected.

Concerning the human intellectual RCCs, our results show that their influence is very limited as a determinant of the different EI types. Only organizational learning seems to have an influence, and only (and negatively) on radical and eco-efficient EIs. At first sight, this could not be expected for systemic and radical EIs. Previous literature has frequently identified knowledge as an important source for these EIs (Horbach, 2008). Some successful SMEs have highly specialized (implicit) knowledge, which may be their most important source of competitive advantage (Cohen and Levinthal, 1990; Sáez-Martínez et al., 2016). Very formalized knowledge could be a barrier to systemic and radical EIs that depend on experimentation and, probably, on tacit knowledge. This is the case with, e.g. solar thermal electricity (Del Río et al., 2018) and off-shore wind (Wieczorek et al., 2013). It can reduce the flexibility to manage or use existing knowledge and to generate new one. Furthermore,

its current total liabilities. Therefore, a company's current ratio is calculated as Current Ratio = Current Assets / Current Liabilities. 
previous knowledge and its management does not seem to be significantly different between all 5 types of EI. It cannot be concluded that different knowledge and different knowledge management is not a driver/barrier of EI; our results just show that it is not a differential driver of distinct EI types. Therefore, hypothesis 5 can be rejected.

Regarding the technological RCCs, having registered patents in the last five years reduces the probability of developing/adopting a radical EI (with respect to the reference EI). This can be regarded as evidence of "path dependency" (see 2.3): a firm registering a patent is more likely to exploit such a patent, focusing on the continuous improvement of an existing EI, rather than engaging in a different technological trajectory, as a radical EI may entail. Therefore, hypothesis 6 cannot be rejected.

Table 8 summarizes the above discussion on the influence of RCCs as drivers or barriers for the different EI types (compared to the reference category). Per EI type, our results show that externally-driven and continuous-improvement EIs, on the one hand, and systemic and radical EIs, on the other, share most determinants. In particular, focusing on the last two categories, physical RCCs, involvement in green supply chains, an EI-friendly corporate culture and internal financing resources represent drivers to these EIs, whereas cooperation, technology-push and market-pull, organizational learning, an ISO ecological certification and technological path dependency are barriers.

\section{Table 8}

\section{Conclusion}

This paper has analyzed the role of RCCs as determinants of different EI types, with a survey of 197 industrial SMEs in Spain which eco-innovated in the observed period.

Regarding the RCCs in eco-innovative firms, an underlying structure has not been identified in some cases. This confirms that, for those cases, the conceptualization of the previous literature provides an accurate representation of the structure of these RCCs. However, our results also suggest that Spanish industrial SMEs have certain peculiarities, since these differ considerably from what it is anticipated by the previous literature. These results contribute to a better understanding of the role of the determinants for EI.

Regarding the relationship of RCCs and EI types, our statistical analyses reveal that, indeed, different RCCs are more or less relevant for different EI types. In particular, the determinants of systemic and radical EIs substantially differ from those for continuous improvements. Physical RCCs, involvement in green supply chains, an EI-friendly corporate 
culture, technology-push and market-pull and internal financing resources represent drivers to these EIs, whereas cooperation, organizational learning, an ISO ecological certification and technological path dependency are barriers.

Overall, these results allow us to infer some policy implications for both public and private decision makers. A main one is that, since the drivers and barriers differ across EI types, the policy measures to encourage different EI types should also be different, in case governments would like to promote a given EI type. Since they may all play a role in a sustainable transition (Braungart et al., 2007; Carrillo-Hermosilla et al., 2010), they may consider promoting all of them, albeit with different policies, intensities and timeframes. In particular, if policy makers are willing to encourage systemic and radical EIs in the Spanish industrial SMEs, then the focus should be on specific policies: improving the availability of physical resources in firms, encouraging the formation of green supply chains and promoting environmental proactivity in firms. Policy makers should thus avoild "one size fits all" policy approaches to eco-innovation in favour of type-specific policies (i.e., Kemp, 2011). Although research increasingly suggests that policies to support eco-innovations should be ecoinnovation-specific, there still seems to be a dominance of generic or "one size fits all" approaches in many contexts. This is probably related to the challenges for policy makers to move towards specific policies for eco-innovation, including lack of knowledge and the need to mitigate the risk of government failure leading to lock-in to inferior technologies. In addition, this might be motivated by the traditional, dominant view in environmental economics thinking and its implications for policy making that governments are not in the best position to "pick winners" and, thus, that technology-neutral policies should be adopted, although this perspective has been shown to lead to suboptimal outcomes (see, e.g., Azar and Sandén, 2011; Grubb et al., 2014; Kemp and Pontoglio, 2011; Sandén and Azar, 2005). Finally, this can also be related to the fact that specific policies for eco-innovation are likely to be more resourceintensive than generic ones, since more information is required in order to design them, which in turn requires devoting public resources to investigate the sectors' features, the existence of sectoral eco-innovation opportunities, the barriers and drivers to their development and diffusion etc... On the other hand, these results inform firms on which RCCs drive different EIs. Some EI types can be more easily pursued than others with given RCCs. In order to pursue a given EI type, this study informs about the corresponding drivers/barriers that the firm can act upon.

As any empirical research, this study has some limitations. The RBV is not the only possible framework to classify firm RCCs. The data are the result of a survey, i.e., not "hard" 
data. Unfortunately, there aren't any clear alternatives to these data. On the other hand, although our theoretical framework and methods are generalizable, i.e., they can be applied to any country, sector and firm type by any researcher willing to identify the drivers and barriers to different EI types in a particular setting, our results are specific to the target universe, i.e., not fully transferable. This is so because the institutional context (including environmental regulation, environmental awareness of the consumers and the national system of innovation) is different across different countries. Future investigations should include countries with different institutional and other characteristics. They should also focus on the determinants in different industrial sectors and non-industrial sectors.

\section{References.}

Adams, R., Jeanrenaud, S., Bessant, J., Overy, P., Denyer, D., 2012. Innovating for Sustainability. Network for Business Sustainability 107. https://doi.org/10.4324/9780203889565

Andersen, M.M., 2002. Organising Interfirm Learning, in: de Bruijn, T., Tukker, A. (Eds.), Partnership and Leadership: Building Alliances for a Sustainable Future. Kluwer Academic Publishers, pp. 103-119.

Andersson, M.M., Lööf, H., 2011. Small business innovation: firm level evidence from Sweden. The Journal of Technology Transfer 37, 732-754.

https://doi.org/10.1007/s10961-011-9216-9

Arundel, A., Kemp, R., Parto, S., 2006. 21 Indicators for environmental innovation: what and how to measure. The international handbook on environmental technology management 324.

Azar, C., Sandén, B.A., 2011. The elusive quest for technology-neutral policies. Environmental Innovation and Societal Transitions 1, 135-139. https://doi.org/10.1016/j.eist.2011.03.003

Azevedo, S.G., Carvalho, H., Cruz Machado, V., 2011. The influence of green practices on supply chain performance: A case study approach. Transportation Research Part E: Logistics and Transportation Review 47, 850-871. https://doi.org/10.1016/j.tre.2011.05.017

Bakar, L.J.A., Ahmad, H., 2010. Assessing the relationship between firm resources and 
product innovation performance: A resource-based view. Business Process Management Journal 16, 420-435. https://doi.org/10.1108/14637151011049430

Barney, J., 1991. Firm Resources and Sustained Competitive Advantage. Journal of Management 17, 99-120.

Belin, J., Horbach, J., Oltra, V., 2011. Determinants and specificities of eco-innovations-an econometric analysis for the French and German industry based on the Community Innovation Survey (No. 2011-17), Cahiers du GREThA.

Blanke, J., Chiesa, T., 2013. The Travel \& Tourism Competitiveness Report 2013, in: The World Economic Forum.

Bocken, N., Short, S., Rana, P., Evans, S., 2014. A literature and practice review to develop Sustainable Business Model Archetypes. Journal of Cleaner Production 65, 42-56. https://doi.org/10.1016/j.jclepro.2013.11.039

Braungart, M., McDonough, W., Bollinger, A., 2007. Cradle-to-cradle design: creating healthy emissions - a strategy for eco-effective product and system design. Journal of Cleaner Production 15, 1337-1348. https://doi.org/10.1016/j.jclepro.2006.08.003

Brío, J.Á., Fernández, E., Junquera, B., 2006. Customer interaction in environmental innovation: the case of cloth diaper laundering. Service Business 1, 141-158. https://doi.org/10.1007/s11628-006-0011-x

Brown, J.R., Fazzari, S.M., Petersen, B.C., 2009. Financing Innovation and Growth: Cash Flow, External Equity, and the 1990s R\&D Boom. The Journal of Fiance LXIV, 151185.

Brown, J.R., Martinsson, G., Petersen, B.C., 2012. Do financing constraints matter for R\&D? European Economic Review 56, 1512-1529. https://doi.org/10.1016/j.euroecorev.2012.07.007

Cai, W., Zhou, X., 2014. On the drivers of eco-innovation: empirical evidence from China. Journal of Cleaner Production 79, 239-248. https://doi.org/10.1016/j.jclepro.2014.05.035

Cainelli, G., De Marchi, V., Grandinetti, R., 2015. Does the development of environmental innovation require different resources? Evidence from Spanish manufacturing firms. Journal of Cleaner Production 94, 211-220. https://doi.org/10.1016/j.jclepro.2015.02.008

Cainelli, G., Mazzanti, M., Montresor, S., 2011. Environmental Innovations, Local Networks 
and Internationalization (No. 20.2011), Sustainable Development Series, Sustainable Development Series. Padova, Italy.

Camisón-Zornoza, C., Lapiedra-Alcamí, R., Segarra-Ciprés, M., Boronat-Navarro, M., 2004. A meta-analysis of innovation and organizational size. Organization Studies 25, 331361.

Carrillo-Hermosilla, J., Del Río, P., Könnölä, T., 2010. Diversity of Eco-innovations: Reflections from selected case studies. Journal of Cleaner Production 18, 1073-1083. https://doi.org/10.1016/j.jclepro.2010.02.014

Castellacci, F., Lie, C.M., 2017. A taxonomy of green innovators: Empirical evidence from South Korea. Journal of Cleaner Production 143, 1036-1047. https://doi.org/10.1093/icc/dtr051

Chassagnon, V., Haned, N., 2015. The relevance of innovation leadership for environmental benefits: A firm-level empirical analysis on French firms. Technological Forecasting and Social Change 91, 194-207. https://doi.org/10.1016/j.techfore.2014.02.012

Cohen, W.M., Levinthal, D.A., 1990. Absorptive Capacity: A New Perspective on Learning and Innovation. Administrative Science Quarterly 35, 128-152.

Cohendet, P., Llerena, P., 1998. Theory of the Firm in an Evolutionary Perspective: A critical Development. Paris.

Cuerva, M.C., Triguero-Cano, Á., Córcoles, D., 2013. Drivers of green and non-green innovation: empirical evidence in Low-Tech SMEs. Journal of Cleaner Production 68, 104-113. https://doi.org/10.1016/j.jclepro.2013.10.049

De Marchi, V., 2012. Environmental innovation and R\&D cooperation: Empirical evidence from Spanish manufacturing firms. Research Policy 41, 614-623. https://doi.org/10.1016/j.respol.2011.10.002

De Marchi, V., Grandinetti, R., 2013. Knowledge strategies for environmental innovations: the case of Italian manufacturing firms. Journal of Knowledge Management 17, 569582. https://doi.org/http://dx.doi.org/10.1108/JKM-03-2013-0121

De Medeiros, J.F., Ribeiro, J.L.D., Cortimiglia, M.N., 2014. Success Factors for Environmentally Sustainable Product Innovation: a Systematic Literature Review. Journal of Cleaner Production 65, 76-86. https://doi.org/10.1016/j.jclepro.2013.08.035 
Del Brío, J.Á., Junquera, B., 2003. A review of the literature on environmental innovation management in SMEs: implications for public policies. Technovation 23, 939-948.

Del Río, P., Carrillo-Hermosilla, J., Könnölä, T., Bleda, M., 2016a. Resources, Capabilities and Competences for Eco-innovation. Technological and Economic Development of Economy 22, 274-292. https://doi.org/10.3846/20294913.2015.1070301

Del Río, P., Peñasco, C., Mir-Artigues, P., 2018. An overview of drivers and barriers to concentrated solar power in the European Union. Renewable and Sustainable Energy Reviews 81, 1019-1029. https://doi.org/10.1016/j.rser.2017.06.038

Del Río, P., Peñasco, C., Romero-Jordán, D., 2016b. What drives eco-innovators? A critical review of the empirical literature based on econometric methods. Journal of Cleaner Production 2158-2170. https://doi.org/10.1016/j.jclepro.2015.09.009

Del Río, P., Romero-Jordán, D., Peñasco, C., 2017. Analysing firm-specific and type-specific determinants of eco-innovation. Technological and Economic Development of Economy 23, 270-295. https://doi.org/10.3846/20294913.2015.1072749

Demirel, P., Kesidou, E., 2011. Stimulating different types of eco-innovation in the UK: Government policies and firm motivations. Ecological Economics 70, 1546-1557. https://doi.org/10.1016/j.ecolecon.2011.03.019

Di Stefano, G., Gambardella, A., Verona, G., 2012. Technology push and demand pull perspectives in innovation studies: Current findings and future research directions. Research Policy 41, 1283-1295. https://doi.org/10.1016/j.respol.2012.03.021

Díaz-García, C., González-Moreno, Á., Sáez-Martínez, F.J., 2015. Eco-innovation: Insights from a literature review. Innovation Management, Policy \& Practice 17, 6-23. https://doi.org/10.1080/14479338.2015.1011060

Díaz-López, F.J., 2008. A Tailored Method for Eco-innovation Strategies and Drivers (in the South), DIME International Conference of Innovation, Sustainability and Policy.

Dosi, G., Nelson, R., Winter, S., 2000. The nature and dynamics of organizational capabilities. Oxford University Press, New York.

Dyer, J.H., Singh, H., 1998. The Relational View: Cooperative Strategy and Sources of Interorganizational Competitive Advantage. Academy of Management Review 23, 660679. 
European Commission, 2017. What is an SME? [WWW Document]. URL

http://ec.europa.eu/growth/smes/business-friendly-environment/sme-definition_de (accessed 3.5.17).

European Commission, 2011. Attitudes of European citizens towards the environment. Special Eurobarometer 365.

Field, A., 2013. Discovering statistics using IBM SPSS statistics. Sage Publications. https://doi.org/10.1024/1012-5302/a000397

Fields, D.L., 2002. Taking the measure of work: A guide to validated scales for organizational research and diagnosis. Sage Publications. https://doi.org/10.4135/9781452231143

Fombrun, C.J., 1996. Reputation. Harvard Business School Press Boston.

Frondel, M., Horbach, J., Rennings, K., 2004. End-of-Pipe or Cleaner Production? An Empirical Comparison of Environmental Innovation Decisions Across OECD Countries (No. No. 04-82), ZEW Discussion Papers.

Geiger, S.W., Makri, M., 2006. Exploration and exploitation innovation processes: The role of organizational slack in R \& D intensive firms. The Journal of High Technology Management Research 17, 97-108. https://doi.org/10.1016/j.hitech.2006.05.007

Ghisetti, C., Marzucchi, A., Montresor, S., 2015. The open eco-innovation mode. An empirical investigation of eleven European countries. Research Policy 44, 1080-1093. https://doi.org/10.1016/j.respol.2014.12.001

Ghisetti, C., Marzucchi, A., Montresor, S., 2013. Does External Knowledge Affect Environmental Innovations? An Empirical Investigation of Eleven European Countries (No. 2013/01), INGENIO (CSIC-UPV) Working Paper Series.

Ghisetti, C., Rennings, K., 2014. Environmental innovations and profitability: how does it pay to be green? An empirical analysis on the German innovation survey. Journal of Cleaner Production 75, 106-117. https://doi.org/10.1016/j.jclepro.2014.03.097

Grant, R.M., 1991. The Resource-based Theory of Competitive Advantage: Implications for Strategy Formulation. California Management Review 33, 114-135.

Grubb, M., Hourcade, J.-C., Neuhoff, K., 2014. Planetary economics: energy, climate change and the three domains of sustainable development. Routledge, London. 
Hair, J.F., Anderson, R.E., Babin, B.J., Black, W.C., 2010. Multivariate data analysis: A global perspective. Pearson Upper Saddle River, NJ.

Hall, B.H., 2002. The Financing of Reseach and Development (No. 8773), NBER WORKING PAPER SERIES.

Hall, R., 1992. The strategic analysis of intangible resources. Strategic Management Journal 13, 135-144.

Halme, M., Korpela, M., 2014. Responsible innovation toward sustainable development in small and medium-sized enterprises: A resource perspective. Business Strategy and the Environment 23, 547-566. https://doi.org/10.1002/bse.1801

Hansen, T., Coenen, L., 2015. The geography of sustainability transitions: Review, synthesis and reflections on an emergent research field. Environmental Innovation and Societal Transitions 17, 92-109. https://doi.org/10.1016/j.eist.2015.07.004

Hart, S.L., 1995. A Natural-Resource-Based View of the Firm. Academy of Management Review 20, 986-1014. https://doi.org/10.2307/258963

Helfat, C., Finkelstein, S., Mitchell, W., Peteraf, M., Singh, H., Teece, D., Winter, S., 2007. Dynamic Capabilities: Understanding Strategic Change in Organizations. Blackwell, Oxford.

Helm, S., 2005. Designing a Formative Measure for Corporate Reputation. Corporate Reputation Review 8, 95-109.

Herstatt, C., Lettl, C., 2004. Management of “Technology Push” Development Projects. International Journal of Technology Management 27, 155.

Hillary, R., 2004. Environmental management systems and the smaller enterprise. Journal of Cleaner Production 12, 561-569.

Hoppmann, J., Peters, M., Schneider, M., Hoffmann, V.H., 2013. The two faces of market support - How deployment policies affect technological exploration and exploitation in the solar photovoltaic industry. Research Policy 42, 989-1003. https://doi.org/10.1016/j.respol.2013.01.002

Horbach, J., 2016. Empirical determinants of eco-innovation in European countries using the community innovation survey. Environmental Innovation and Societal Transitions 19, 114. https://doi.org/10.1016/j.eist.2015.09.005 
Horbach, J., 2008. Determinants of environmental innovation-New evidence from German panel data sources. Research Policy 37, 163-173. https://doi.org/10.1016/j.respol.2007.08.006

Horbach, J., Jabob, J., 2018. The relevance of personal characteristics and gender diversity for (eco)-innovation activities at the firm-level. Results from a linked employer-employee database in Germany. Business Strategy and the Environment 1-11. https://doi.org/10.1002/bse.2042

Horbach, J., Rammer, C., Rennings, K., 2012. Determinants of eco-innovations by type of environmental impact — The role of regulatory push/pull, technology push and market pull. Ecological Economics 78, 112-122. https://doi.org/10.1016/j.ecolecon.2012.04.005

IEA, 2015. Key World Energy Statistics, Key World Energy Statistics.

Jaffe, A.B., Newell, R.G., Stavins, R.N., 2005. A tale of two market failures: Technology and environmental policy. Ecological Economics 54, 164-174. https://doi.org/10.1016/j.ecolecon.2004.12.027

Johnstone, N., Hascic, I., Popp, D., 2010. Renewable energy policies and technological innovation: Evidence based on patent counts. Environmental and Resource Economics 45, 133-155. https://doi.org/10.1007/s10640-009-9309-1

Jové-Llopis, E., Segarra-Blasco, A., 2018. Eco-innovation strategies: A panel data analysis of Spanish manufacturing firms. Business Strategy and the Environment 1-12. https://doi.org/10.1002/bse.2063

Junquera, B., Del Brío, J.Á., Fernández, E., 2012. Clients' involvement in environmental issues and organizational performance in businesses: an empirical analysis. Journal of Cleaner Production 37, 288-298. https://doi.org/10.1016/j.jclepro.2012.07.029

Kabongo, J.D., Boiral, O., 2017. Doing More with Less: Building Dynamic Capabilities for Eco-Efficiency. Business Strategy and the Environment 26, 956-971. https://doi.org/10.1002/bse.1958

Kammerer, D., 2009. The effects of customer benefit and regulation on environmental product innovation. Ecological Economics 68, 2285-2295. https://doi.org/10.1016/j.ecolecon.2009.02.016

Kanda, W., Clausen, J., Hjelm, O., Bienkowska, D., 2015. Functions of intermediaries in eco- 
innovation: a study of business development organizations and cluster initiatives in a Swedish and a German region, in: Global Cleaner Production and Sustainable Consumption Conference, 1-4 November. Sitges.

Kanda, W., Sakao, T., Hjelm, O., 2016. Components of business concepts for the diffusion of large scaled environmental technology systems. Journal of Cleaner Production 128, 156167. https://doi.org/10.1016/j.jclepro.2015.10.040

Karltorp, K., Guo, S., Sandén, B.A., 2017. Handling financial resource mobilisation in technological innovation systems - The case of chinese wind power. Journal of Cleaner Production 142, 3872-3882. https://doi.org/10.1016/j.jclepro.2016.10.075

Katkalo, V., Pitelis, C., Teece, D., 2010. Introduction: On the Nature and Scope of Dynamic Capabilities. Industrial and corporate change 19, 1175-1186. https://doi.org/10.1093/icc/dtq026

Kemp, R., 2011. Ten themes for eco-innovation policies in Europe. Sapiens 4, 1-20.

Kemp, R., 1994. Technology and the transition to environmental sustainability. Futures 26, 1023-1046. https://doi.org/10.1016/0016-3287(94)90071-X

Kemp, R., Pontoglio, S., 2011. The innovation effects of environmental policy instruments A typical case of the blind men and the elephant? Ecological Economics 72, 28-36. https://doi.org/10.1016/j.ecolecon.2011.09.014

Kesidou, E., Demirel, P., 2012. On the drivers of eco-innovations: Empirical evidence from the UK. Research Policy 41, 862-870. https://doi.org/10.1016/j.respol.2012.01.005

Keskin, D., Diehl, J.C., Molenaar, N., 2013. Innovation process of new ventures driven by sustainability. Journal of Cleaner Production 45, 50-60. https://doi.org/10.1016/j.jclepro.2012.05.012

Khanna, M., Deltas, G., Harrington, D.R., 2009. Adoption of Pollution Prevention Techniques: The Role of Management Systems and Regulatory Pressures. Environmental and Resource Economics 44, 85-106. https://doi.org/10.1007/s10640009-9263-y

Kiefer, C.P., Carrillo-Hermosilla, J., Del Río, P., 2018. A Taxonomy of Eco-innovation Types in Firms (No. 1/2018), Documentos de trabajo.

Kiefer, C.P., Carrillo-Hermosilla, J., Del Río, P., Callealta Barroso, F.J., 2017. Diversity of 
eco-innovations: a quantitative approach. Journal of Cleaner Production 166, 1494-1506. https://doi.org/10.1016/j.jclepro.2017.07.241

Kitchell, S., 1995. Corporate Culture, Environmental Adaptation, and Innovation Adoption: a Qualitative/Quantitative Approach. Journal of the Academy of Marketing Science 23, 195-205.

Könnölä, T., Unruh, G.C., 2007. Really Changing the Course: the Limitations of Environmental Management Systems for Innovation. Business Strategy \& the Environment 537, 525-537. https://doi.org/10.1002/bse.487

Könnölä, T., Unruh, G.C., Carrillo-Hermosilla, J., 2006. Prospective voluntary agreements for escaping techno-institutional lock-in. Ecological Economics 57, 239-252. https://doi.org/10.1016/j.ecolecon.2005.04.007

Kuha, J., 2004. AIC and BIC: Comparisons of Assumptions and Performance. Sociological methods \& research 33, 188-229.

López-Nicolás, C., Meroño-Cerdán, Á.L., 2011. Strategic knowledge management, innovation and performance. International Journal of Information Management 31, 502509. https://doi.org/10.1016/j.ijinfomgt.2011.02.003

Machiba, T., 2010. Eco-innovation for Enabling Resource Efficiency and Green Growth: Development of an Analytical Framework and Preliminary Analysis of Industry and Policy Practices. International Economics of Resource Efficiency 7, 357-370. https://doi.org/10.1007/s10368-010-0171-y

Marin, G., Marzucchi, A., Zoboli, R., 2014. SMEs and Barriers to Eco-Innovation in EU: A Diverse Palette of Greens. SEEDS Working Papers. https://doi.org/10.1007/s00191-0150407-7

Markard, J., Worch, H., 2010. Technological innovation systems and the resource based view - Resources at the firm, network and system level.

Marlin, D., Geiger, S.W., 2015. A reexamination of the organizational slack and innovation relationship. Journal of Business Research 68, 2683-2690. https://doi.org/10.1016/j.jbusres.2015.03.047

Martín-de-Castro, G., Delgado-Verde, M., López-Sáez, P., Navas-López, J.E., 2011. Towards "An Intellectual Capital-Based View of the Firm": Origins and Nature. Journal of 
Business Ethics 98, 649-662. https://doi.org/10.1007/s10551-010-0644-5

Mazzanti, M., Zoboli, R., 2009. Embedding environmental innovation in local production systems: SME strategies, networking and industrial relations: evidence on innovation drivers in industrial districts. International Review of Applied Economics 23, 169-195.

Mazzanti, M., Zoboli, R., 2006. Examining the Factors Influencing Environmental Innovations (No. 20.2006), Nota di Lavoro, Fondazione Eni Enrico Mattei.

Mellahi, K., Wilkinson, A., Mallahi, K., Wilkinson, A., 2010. A Study of the Association between Level of Slack Reduction Following Downsizing and Innovation Output. Journal of Management Studies 47, 483-508. https://doi.org/10.1111/j.14676486.2009.00872.x

Nahapiet, J., Ghoshal, S., 1998. Social capital and the organizational advantage. Academy of Management Journal 23, 242-266. https://doi.org/10.2307/259373

Nelson, R.R., Winter, S.G., 1982. An evolutionary theory of economic change. Harvard University Press, Cambridge, MA.

Nemet, G.F., 2009. Demand-pull, technology-push, and government-led incentives for nonincremental technical change. Research Policy 38, 700-709. https://doi.org/10.1016/j.respol.2009.01.004

Nohria, N., Gulati, R., 1997. What is the Optimum Amount of Organizational Slack?: A Study of the Relationship Between Slack and Innovation in Multinational Firms. European Management Journal 15, 603-611.

Nohria, N., Gulati, R., 1996. Is Slack Good or Bad for Innovation? Academy of Management Journal 39, 1245-1264.

Nonaka, I., 1994. A Dynamic Theory of Organizational Knowledge Creation. Organization Science 5, 14-37.

Nonaka, I., 1991. The Knowledge-creating Company. Harvard Business Review 96, 96-104.

Nunnally, J.C., 1978. Psychometric theory. Mc Graw-Hill Publ Co, Psychometric Theory. McGraw Hill, New York.

OECD/Eurostat, 2005. Oslo Manual. Guidelines for Collecting and Interpreting Innovation Data, in: The Measurement of Scientific and Technological Activities. OECD 
Publishing, Paris, pp. 1-113. https://doi.org/10.1787/9789264013100-en

OECD, 2012. The Future of Eco-Innovation: The Role of Business Models in Green Transformation, OECD Background Paper. Copenhagen.

OECD, 2009. Eco-Innovation in Industry. Enabling Green Growth. OECD Publishing, Paris. https://doi.org/10.1787/9789264077225-en

Penrose, E., 1959. The Theory of the Growth of the Firm. Wiley, New York.

Perez, C., 2011. Finance and technical change: a long-term view. African Journal of Science, Technology, Innovation and Development 3, 10-35.

Polzin, F., Flotow, P. Von, Klerkx, L., 2016. Addressing barriers to eco-innovation : Exploring the finance mobilisation functions of institutional innovation intermediaries. Technological Forecasting \& Social Change 103, 34-46. https://doi.org/10.1016/j.techfore.2015.10.001

Rave, T., Goetzke, F., Larch, M., 2011. The Determinants of Environmental Innovations and Patenting: Germany Reconsidered (No. Nr. 97), Ifo Working Paper.

Rehfeld, K.-M., Rennings, K., Ziegler, A., 2007. Integrated product policy and environmental product innovations: An empirical analysis. Ecological Economics 61, 91-100. https://doi.org/10.1016/j.ecolecon.2006.02.003

Rennings, K., 2000. Redefining innovation - eco-innovation research and the contribution from ecological economics. Ecological Economics 32, 319-332. https://doi.org/10.1016/S0921-8009(99)00112-3

Rennings, K., Ziegler, A., 2004. Determinants of Environmental Innovations in Germany: Do Organizational Measures Matter? A Discrete Choice Analysis at the Firm Level (No. 0430), ZEW Discussion Papers.

Rennings, K., Ziegler, A., Ankele, K., Hoffmann, E., 2006. The influence of different characteristics of the EU environmental management and auditing scheme on technical environmental innovations and economic performance. Ecological Economics 57, 45-59. https://doi.org/10.1016/j.ecolecon.2005.03.013

Russo, M. V., Fouts, P.A., 1997. A Resource-Based Perspective on Corporate Environmental Performance and Profitability. Academy of Management Journal 40, 534-559. 
Sáez-Martínez, F.J., Díaz-García, C., Gonzalez-Moreno, A., 2016. Firm technological trajectory as a driver of eco-innovation in young small and medium-sized enterprises. Journal of Cleaner Production 138, 28-37. https://doi.org/10.1016/j.jclepro.2016.04.108

Sandén, B.A., Azar, C., 2005. Near-term technology policies for long-term climate targets Economy wide versus technology specific approaches. Energy Policy 33, 1557-1576. https://doi.org/10.1016/j.enpol.2004.01.012

Segarra-Oña, M. del V., Peiró-Signes, A., Albors-Garrigós, J., Miret-Pastor, P., 2011. Impact of innovative practices in environmentally focused firms: moderating factors. International Journal of Environmental Research 5, 425-434.

Simpson, D., Power, D., Samson, D., 2007. Greening the automotive supply chain: a relationship perspective. International Journal of Operations \& Production Management 27, 28-48. https://doi.org/10.1108/01443570710714529

Teece, D., Pisano, G., 1994. The dynamic capabilities of firms: an introduction. Industrial and corporate change $3,537-556$.

Teece, D.J., Pisano, G., Shuen, A., 1997. Dynamic Capabilities and Strategic Management. Strategic Management Journal 18, 509-533.

Testa, F., Iraldo, F., 2010. Shadows and lights of GSCM (Green Supply Chain Management): determinants and effects of these practices based on a multi-national study. Journal of Cleaner Production 18, 953-962. https://doi.org/10.1016/j.jclepro.2010.03.005

Triguero, A., Moreno-Mondéjar, L., Davia, M. a., 2013. Drivers of different types of ecoinnovation in European SMEs. Ecological Economics 92, 25-33. https://doi.org/10.1016/j.ecolecon.2013.04.009

Unruh, G.C., 2000. Understanding Carbon Lock-in. Energy Policy 28, 817-830.

Vachon, S., Klassen, R.D., 2006. Extending green practices across the supply chain: The impact of upstream and downstream integration. International Journal of Operations \& Production Management 26, 795-821. https://doi.org/10.1108/01443570610672248

Van Kleef, J. a. G., Roome, N., 2007. Developing capabilities and competence for sustainable business management as innovation: a research agenda. Journal of Cleaner Production 15, 38-51. https://doi.org/10.1016/j.jclepro.2005.06.002

Wagner, M., Llerena, P., 2011. Eco-innovation through integration, regulation and 
cooperation: comparative insights from case studies in three manufacturing sectors. Industry and Innovation 18, 747-764.

Wieczorek, A.J., Negro, S.O., Harmsen, R., Heimeriks, G.J., Luo, L., Hekkert, M.P., 2013. A review of the European offshore wind innovation system. Renewable and Sustainable Energy Reviews 26, 294-306. https://doi.org/10.1016/j.rser.2013.05.045

Wong, T.Y.T., Peko, G., Sundaram, D., Piramuthu, S., 2015. Mobile Environments and the Innovation Co-creation Processes and Ecosystems. Information \& Management. https://doi.org/10.1016/j.im.2015.09.005

Wu, K., Liao, C., Chen, C., Lin, Y., Tsai, C.F.M., 2015. Exploring eco-innovation in dynamic organizational capability under incomplete information in the Taiwanese lighting industry. Intern. Journal of Production Economics. https://doi.org/10.1016/j.ijpe.2015.10.007

Yang, K.-P., Chou, C., Chiu, Y.-J., 2014. How unlearning affects radical innovation: The dynamics of social capital and slack resources. Technological Forecasting and Social Change 87, 125-163. https://doi.org/10.1016/j.techfore.2013.12.014 


\section{TABLES}

\section{Table 1. Different types of EIs considered in this article.}

According to Kiefer et al. (2018), the Spanish industrial SMEs analyzed during the period (2012-2014) have carried out 5 EI types:

1.- Systemic EIs. They have high degrees of novelty, involve a rupture with existing solutions, lead to considerable environmental benefits throughout their life cycle and create a new base for competitiveness.

2.- Externally driven EIs. They have nonspecific technological or environmental features and are developed or adopted as a result of external pressures from society or legislation.

3.- Continuous improvement EIs. They also have nonspecific technological or environmental features. They emerge from within the SME as a result of daily business practices and they are fully compatible with existing processes and systems. They entail small improvements with respect to existing solutions.

4.- Radical and technology-push EIs. They are characterized by high degrees of technological novelty, a rupture with existing solutions and considerable environmental benefits. They emerge as a result of a push from science and technology research.

5.- Eco-efficient EIs. They increase the efficiency of products, services or processes, leading to environmental benefits as a result.

Source: Kiefer et al. (2018). See Kiefer et al. (2018) for a detailed discussion on how those EIs were derived. 
Table 2. Describing different types of RCCs and their impact on EI.

\begin{tabular}{|c|c|}
\hline RCC & Description and impact on EI \\
\hline Physical & $\begin{array}{l}\text { These include all of the company's tangible assets such as machinery, real estate, land, as well as access to and spatial distribution of these assets (Bakar } \\
\text { and Ahmad, 2010). According to the RBV, physical resources condition the capacity to eco-innovate (Khanna et al., 2009; Teece and Pisano, 1994). } \\
\text { The concept of the level of availability of physical resources (Geiger and Makri, 2006) encompasses the set of physical resources available in an } \\
\text { organization that exceeds the minimum level necessary to create a given organizational outcome (Geiger and Makri, 2006; Nohria and Gulati, 1996). } \\
\text { Availability levels above this minimum are called "physical slack" and have direct impacts on (eco-)innovative activity (Geiger and Makri, 2006). } \\
\text { According to Organizational Theory, the additional availability of physical resources stimulates eco-innovation processes because it facilitates } \\
\text { experimentation and exploration without jeopardizing the firm's "core" activities. However, Agency Theory estimates that this additional availability } \\
\text { increases the undisciplined and inefficient use of physical resources due to unbalanced information between principals and agents, constituting a barrier } \\
\text { to eco-innovation (Mellahi et al., 2010; Nohria and Gulati, 1996). The relationship between (eco-)innovation activities and physical slack has an } \\
\text { "inverted-U" type (Nohria and Gulati, 1997, 1996). There is an optimal amount of physical slack that allows experimentation/exploration without losing } \\
\text { sight of the discipline in the use of these resources. Finally, the degree of novelty of major physical assets interferes with eco-innovation. On the one } \\
\text { hand, relatively old physical assets tend to be less ecological and potentially less flexible for new eco-innovative processes or products. On the other } \\
\text { hand, their replacement cost is lower (they tend to be amortized) and the ecological improvements due to their replacement are higher than with newer } \\
\text { physical assets. }\end{array}$ \\
\hline $\begin{array}{l}\text { Reputational and } \\
\text { cooperational }\end{array}$ & $\begin{array}{l}\text { The reputation as an intangible asset is a main RCC of firms (Hall, 1992). It is created on the basis of perceptions of known firm behavior and future } \\
\text { prospects, which leads to the attractiveness of the firm compared to its rivals (Fombrun, 1996) in terms of quality of products and services, the value- } \\
\text { price ratio, relations with firm stakeholders including employees, corporate success and economic, ecological and social objectives pursued (Helm, } \\
\text { 2005). Consumers, businesses and institutions are increasingly aware of the need to transition towards more sustainable economies and societies (Adams } \\
\text { et al., 2012; Bocken et al., 2014). Cooperation is of high importance for eco-innovation because of its characteristics such as the double externality } \\
\text { including positive spillovers (Jaffe et al., 2005; Rennings, 2000). In addition, the transition to sustainable production and consumption patterns requires } \\
\text { the involvement of several private and public actors in a system (Carrillo-Hermosilla et al., 2010; Hansen and Coenen, 2015). } \\
\text { The breath is as important as the depth of cooperation (Junquera et al., 2012). Eco-innovations imply organizational and institutional changes. They } \\
\text { require the availability of adequate technological knowledge that is almost impossible to satisfy only internally. The availability of a breadth of } \\
\text { cooperation with different types of organizations is a valuable resource in this context. }\end{array}$ \\
\hline
\end{tabular}




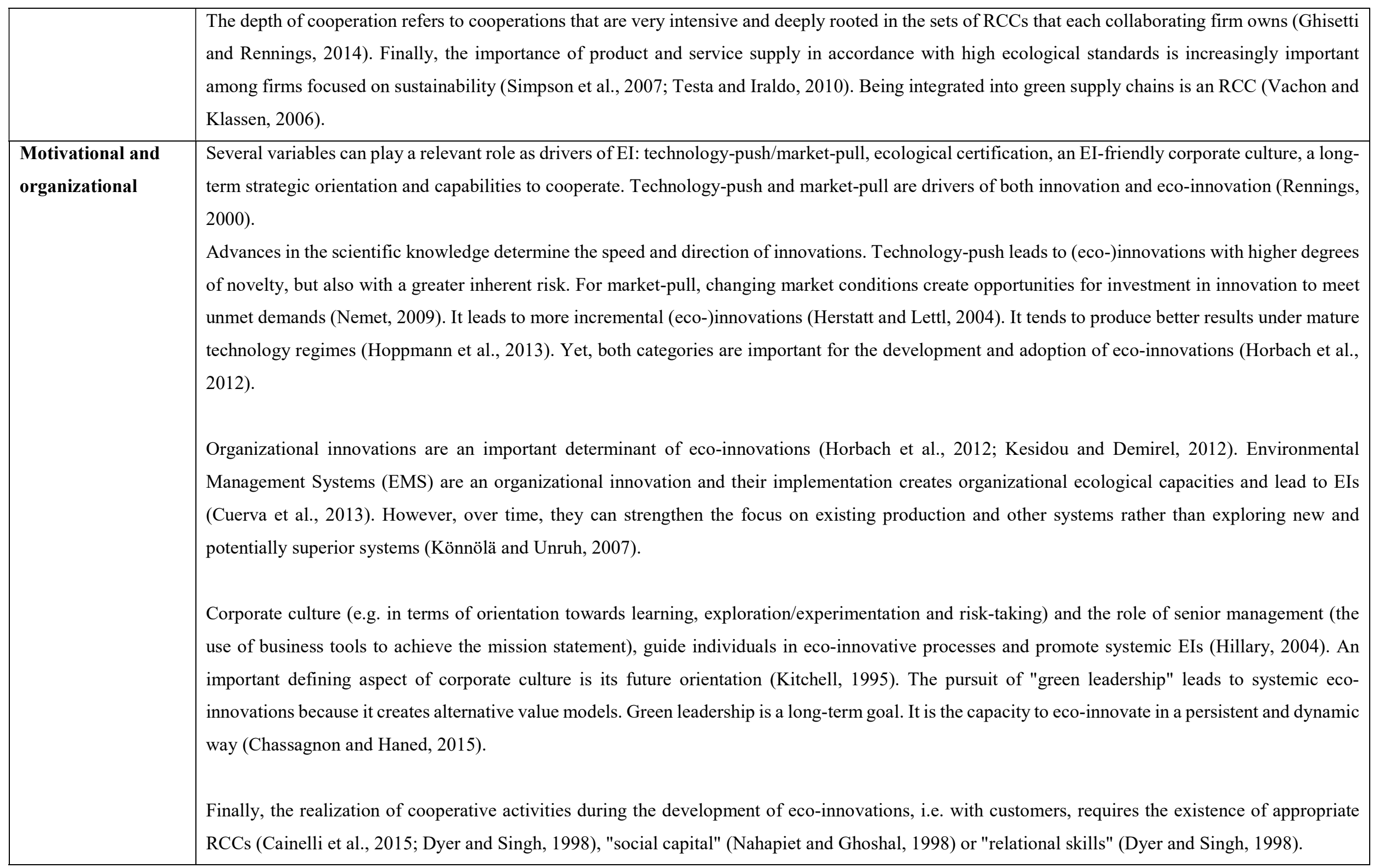




\begin{tabular}{|c|c|}
\hline & $\begin{array}{l}\text { activate cooperations in a first step, up-to-date systematic knowledge about customers should be created and maintained (De Marchi and Grandinetti, } \\
\text { 13). It can be formalized in databases or customer relationship management (CRM) systems (Wong et al., 2015). The existence of contact points } \\
\text { tween customers and the firm, such as key account managers, facilitates this cooperation. }\end{array}$ \\
\hline & $\begin{array}{l}\text { Three financial RCCs can be relevant as determinants of EI: the type of financing used to develop/adopt an EI, the availability of financial resources and } \\
\text { the financial slack and the profitability measures. Access to financing, both internal and external, is an important RCC. Notwithstanding, the "cheapest" } \\
\text { financing, as the result of the accumulation of cash flows, is internal financing. External financing (debt or, even more so, shares) is more "expensive" } \\
\text { because of its association with adverse selection (Brown et al., 2009; Hall, 2002). } \\
\text { The availability of financial resources themselves or financial slack influences EIs. This refers to the availability of financial resources above the } \\
\text { minimum level for given business operations (Nohria and Gulati, 1996). According to Behavioral and Agency Theories (Marlin and Geiger, 2015; } \\
\text { Nohria and Gulati, 1997, 1996), more financial resources translate into more (eco-)innovation through experimentation (Camisón-Zornoza et al., 2004). } \\
\text { On the other hand, unlimited R\&D funding can reduce the motivation to (eco-)innovate and promote undisciplined investments that does not translate } \\
\text { into corresponding yields. But, at the same time, it can facilitate the realization of more expensive projects (exploration/experimentation) and encourage } \\
\text { an innovative culture. } \\
\text { Therefore, an inverted-U relationship between the availability of financial resources and (eco-)innovation can be proposed (Nohria and Gulati, 1997, } \\
\text { 1996). }\end{array}$ \\
\hline Human intellectual & $\begin{array}{l}\text { Involvement in R\&D activities (investments and dedicated staff), training of staff and formalization of knowledge management in the firm are relevant } \\
\text { RCCs. } \\
\text { Active knowledge management (dynamic capacity) translates into greater innovative performance (López-Nicolás and Meroño-Cerdán, 2011). This is } \\
\text { especially the case with radical and disruptive innovations (Yang et al., 2014). R\&D activities create "technological capabilities" and "knowledge capital" } \\
\text { (Martín-de-Castro et al., 2011), which are important antecedents for eco-innovations (Horbach, 2016, 2008). Eco-innovative activity depends directly } \\
\text { on R\&D activity, which is influenced by past activities (dependence on the technological trajectory) and activities of other companies in the same } \\
\text { industry/sector (technological regime) (Castellacci and Lie, 2017; Horbach, 2016; Sáez-Martínez et al., 2016). } \\
\text { On the other hand, the knowledge needed to develop eco-innovations tends to differ from that needed to innovate traditionally (De Marchi, 2012; De } \\
\text { Marchi and Grandinetti, 2013). Staff training and education can increase or maintain the quality and quantity of available knowledge and thus directly } \\
\text { influence (eco-)innovative outcomes (Cainelli et al., 2015; Horbach, 2016). Training transmits (technological) knowledge but also raises awareness of }\end{array}$ \\
\hline
\end{tabular}




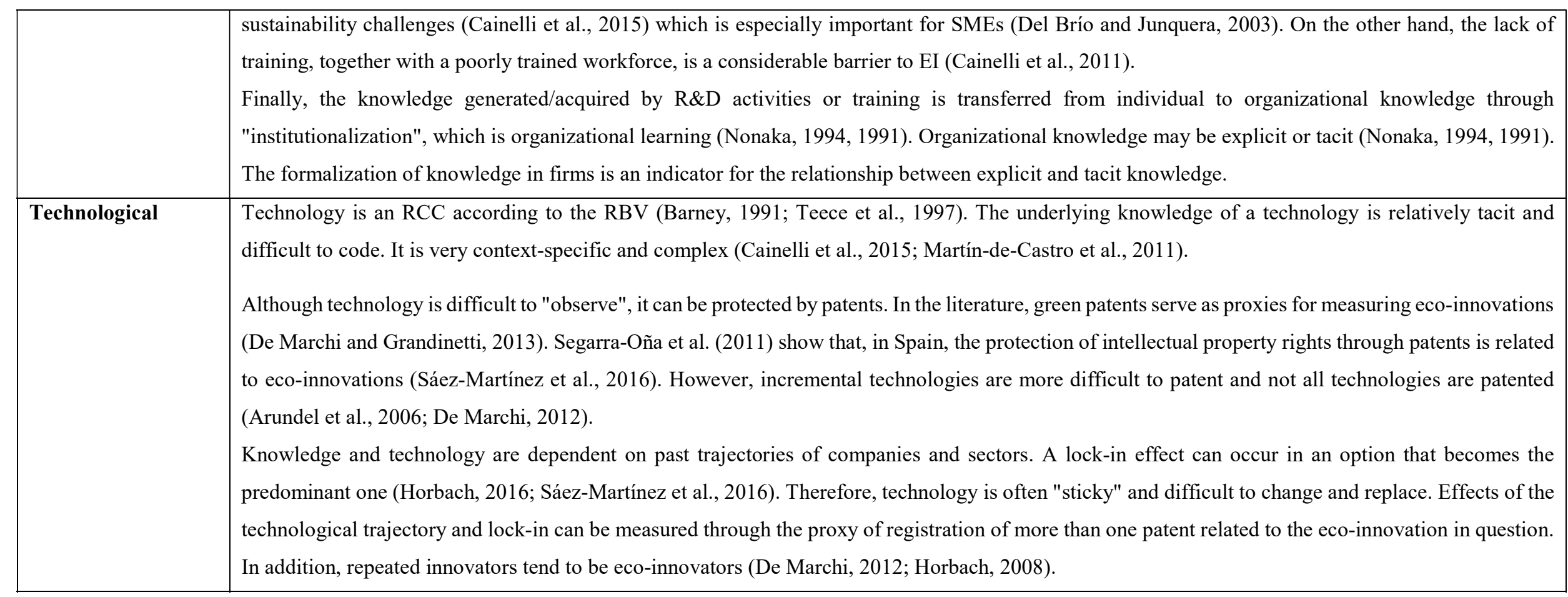

Source: Own elaboration. 
Table 3. RCCs: description of variables.

\begin{tabular}{|c|c|c|}
\hline Variable/Code & Question & Scale/quantification \\
\hline \multicolumn{3}{|c|}{ PHYSICAL RCCs } \\
\hline $\begin{array}{l}\text { Perceived slack } \\
\text { of physical } \\
\text { RCCs }\end{array}$ & $\begin{array}{l}\text { During the process of development/adoption of this EI, has your } \\
\text { firm experienced any restriction in the availability of physical } \\
\text { resources (materials, labs and devices)? }\end{array}$ & Likert scale (1-5). \\
\hline $\begin{array}{l}\text { Degree of use of } \\
\text { physical RCCs }\end{array}$ & What degree of average use do your physical resources have? & Percentage \\
\hline $\begin{array}{l}\text { Flexibility of } \\
\text { physical RCCs }\end{array}$ & $\begin{array}{l}\text { Which percentage of your physical resources do not belong } \\
\text { directly to your firm? }\end{array}$ & Percentage \\
\hline $\begin{array}{l}\text { Existence of } \\
\text { physical RCCs }\end{array}$ & Tangible fixed assets. & Monetary values. \\
\hline $\begin{array}{l}\text { Degree of } \\
\text { novelty of RCCs }\end{array}$ & $\begin{array}{l}\text { On average, how novel are the main physical assets used in your } \\
\text { production processes? }\end{array}$ & Likert scale (1-5). \\
\hline \multicolumn{3}{|c|}{ REPUTATIONAL AND COOPERATIONAL RCCS } \\
\hline $\begin{array}{l}\text { Retention of } \\
\text { clients due to the } \\
\text { corporate } \\
\text { reputation. }\end{array}$ & $\begin{array}{l}\text { What percentage of private and public clients regularly buy the } \\
\text { products of your company? }\end{array}$ & Percentage \\
\hline $\begin{array}{l}\text { Eco-innovative } \\
\text { "clusters" }\end{array}$ & $\begin{array}{l}\text { On average, how do you rate the geographical proximity of } \\
\text { frequently collaborating firms? }\end{array}$ & Likert scale (1-5). \\
\hline $\begin{array}{l}\text { Sustainable } \\
\text { supply } \\
\text { chains/networks }\end{array}$ & $\begin{array}{l}\text { How important is that the supply of goods/services to your firm is } \\
\text { done according to high ecological standards? }\end{array}$ & Likert scale (1-5). \\
\hline $\begin{array}{lr}\text { Breadth and } \\
\text { depth } & \text { of } \\
\text { cooperation } & \end{array}$ & $\begin{array}{l}\text { During the process of development/adoption of this EI, how } \\
\text { frequently has your firm collaborated with the following } \\
\text { organizations? Organizations: Equipment suppliers, clients/users, } \\
\text { competitors, consultants, private and public research centers, } \\
\text { universities, public administrations, professional and industrial } \\
\text { associations, conferences, fairs and expositions, scientific } \\
\text { publications, NGOs and private associations. How important has } \\
\text { this collaboration been? }\end{array}$ & $\begin{array}{l}\text { Likert scale (1-3). Breadth of } \\
\text { cooperation is the aggregation of } \\
\text { the number of cooperations with } \\
\text { median and high frequencies. } \\
\text { Depth of cooperation is the } \\
\text { aggregation of the number of } \\
\text { cooperation with a high } \\
\text { importance. }\end{array}$ \\
\hline \multicolumn{3}{|c|}{ MOTIVATIONAL AND ORGANIZATIONAL RCCs } \\
\hline $\begin{array}{l}\text { Main } \\
\text { motivation: } \\
\text { Technology- } \\
\text { push / Market- } \\
\text { pull }\end{array}$ & $\begin{array}{l}\text { What has been the main motivation for developing/adopting this } \\
\text { EI? }\end{array}$ & $\begin{array}{l}\text { Nominal Scale (advancing } \\
\text { technological limits and adopting } \\
\text { something new, satisfying an } \\
\text { existing demand in the market, } \\
\text { both, others) }\end{array}$ \\
\hline $\begin{array}{l}\text { Ecological } \\
\text { certification }\end{array}$ & Does your firm have an ISO14001/EMAS certification? & Dichotomous scale \\
\hline
\end{tabular}




\begin{tabular}{|c|c|c|}
\hline $\begin{array}{l}\text { Orientation of } \\
\text { corporate } \\
\text { culture towards } \\
\text { sustainability }\end{array}$ & $\begin{array}{l}\text { To what extent is the mission and culture of your firm oriented } \\
\text { towards EI? }\end{array}$ & Likert scale (1-5). \\
\hline $\begin{array}{l}\text { Future } \\
\text { orientation of } \\
\text { the main } \\
\text { corporate goals }\end{array}$ & $\begin{array}{l}\text { To what extend are the objectives pursued by your firm in the } \\
\text { process of development/adoption of this EI oriented towards the } \\
\text { future? }\end{array}$ & Likert scale (1-5). \\
\hline $\begin{array}{l}\text { Cooperation } \\
\text { skills (I): CRM }\end{array}$ & $\begin{array}{l}\text { Does your firm maintain an updated database of clients or any } \\
\text { CRM system (management of relationships with clients)? }\end{array}$ & Dichotomous scale \\
\hline $\begin{array}{l}\text { Cooperation } \\
\text { skills (II): key } \\
\text { account } \\
\text { management }\end{array}$ & $\begin{array}{l}\text { Do your main clients have a key account manager at their } \\
\text { disposal? }\end{array}$ & Dichotomous scale \\
\hline $\begin{array}{l}\text { Cooperation } \\
\text { skills (III): } \\
\text { Frequency of } \\
\text { client visits }\end{array}$ & $\begin{array}{l}\text { How often do the top managers in your firm visit or contact } \\
\text { clients? }\end{array}$ & Likert scale (1-5). \\
\hline \multicolumn{3}{|c|}{ FINANCIAL RCCs } \\
\hline $\begin{array}{l}\text { Type of } \\
\text { financing }\end{array}$ & $\begin{array}{l}\text { What type of financing has been mainly used for the development } \\
\text { or adoption of this EI? }\end{array}$ & Internal/External financing \\
\hline $\begin{array}{l}\text { Profitability } \\
\text { measures } \quad \text { (I): } \\
\text { capital }\end{array}$ & Profitability of capital & Percentage \\
\hline $\begin{array}{l}\text { Profitability } \\
\text { measures (II): } \\
\text { assets }\end{array}$ & Profitability of assets. & Percentage \\
\hline $\begin{array}{l}\text { Availability of } \\
\text { financial } \\
\text { resources and } \\
\text { "financial } \\
\text { slack" }\end{array}$ & $\begin{array}{l}\text { Has your firm experienced any restriction in the financing of the } \\
\text { development/adoption of this EI? }\end{array}$ & Likert scale (1-5). \\
\hline $\begin{array}{l}\text { Ratios of } \\
\text { "financial } \\
\text { slack" } \\
\text { Current Ratio }\end{array}$ & Current Ratio & Continuous scale \\
\hline $\begin{array}{ll}\text { Ratios } & \text { of } \\
\text { "financial } & \\
\text { slack" } & \text { (II): } \\
\text { Working } & \\
\text { Capital } & \end{array}$ & Working Capital & Continuous scale \\
\hline $\begin{array}{l}\text { Ratios of } \\
\text { "financial }\end{array}$ & Gearing (Debt-to-equity ratio) & Continuous scale \\
\hline
\end{tabular}




\begin{tabular}{|c|c|c|}
\hline $\begin{array}{ll}\text { slack" (III): } \\
\text { Gearing }\end{array}$ & & \\
\hline \multicolumn{3}{|c|}{ HUMAN INTELLECTUAL RCCS } \\
\hline $\begin{array}{l}\text { R\&D } \\
\text { expenditures }\end{array}$ & $\begin{array}{l}\text { What share of the total investments of your company has been } \\
\text { dedicated to R\&D in the last year? }\end{array}$ & Percentage \\
\hline R\&D staff & $\begin{array}{l}\text { What percentage of the total staff of your company is exclusively } \\
\text { dedicated to R\&D activities? }\end{array}$ & Percentage \\
\hline $\begin{array}{ll}\text { Amount } & \text { of } \\
\text { budget } & \\
\text { dedicated } & \text { to } \\
\text { training } & \end{array}$ & $\begin{array}{l}\text { What budget has been dedicated to training of your staff in the last } \\
\text { year? }\end{array}$ & Monetary values (€/employee) \\
\hline $\begin{array}{l}\text { Formalization } \\
\text { of knowledge }\end{array}$ & $\begin{array}{l}\text { What is the degree of formalization of the management of } \\
\text { knowledge in your firm? }\end{array}$ & Likert scale (1-5). \\
\hline \multicolumn{3}{|c|}{ TECHNOLOGICAL RCCs } \\
\hline Patents & Has your firm registered any patent in the last 5 years? & Dichotomous scale \\
\hline $\begin{array}{l}\text { Technological } \\
\text { trajectory / lock- } \\
\text { in }\end{array}$ & Number of patents registered in the context of the EI. & Natural numbers \\
\hline
\end{tabular}

Source: Own elaboration.

\section{Table 4. Details on the procedure}

\begin{tabular}{ll}
\hline & Number \\
\hline Firms in the target universe & 2821 \\
Identified contact persons & 2206 \\
Surveys accessed & 638 \\
Surveys completed & 430 \\
Response rate & $28.9 \%$ of contacts \\
& $22.6 \%$ of target universe \\
\hline Firms developing/adopting an EI & 197 \\
\hline
\end{tabular}

Source: Own elaboration.

Table 5. Details on the final sample (eco-innovators and EIs)

\begin{tabular}{|c|c|c|}
\hline \multicolumn{3}{|c|}{ Eco-innovators } \\
\hline \multirow[t]{3}{*}{ Target market (\% of firms) } & B2B & 65.0 \\
\hline & $\mathrm{B} 2 \mathrm{C}$ & 4.6 \\
\hline & Both & 27.9 \\
\hline Foreign economic activity (\% of firms) & Exports and imports & 71.6 \\
\hline
\end{tabular}




\begin{tabular}{|c|c|c|}
\hline & Exports & 13.7 \\
\hline & Imports & 4.6 \\
\hline & No foreign activity & 10.2 \\
\hline Age (years) & \multicolumn{2}{|c|}{30 (average) } \\
\hline Size (number of employees) & \multicolumn{2}{|c|}{107 (average) } \\
\hline \multirow[t]{3}{*}{ Legal form ( $\%$ of firms) } & Public limited companies & 59.9 \\
\hline & Limited liability companies & 39.6 \\
\hline & Cooperatives & 0.5 \\
\hline \multicolumn{3}{|c|}{ EIs } \\
\hline \multirow[t]{2}{*}{ Degree of novelty for the firm ( $\%$ of firms) } & New to the firm & 53.8 \\
\hline & Not new to the firm & 39.1 \\
\hline \multirow[t]{2}{*}{ Degree of novelty (\% of all firms) } & New to the sector & 12.7 \\
\hline & Not new to the sector & 61.4 \\
\hline \multirow[t]{5}{*}{ Origin of the EI ( $\%$ of all EIs) } & Developed in-house & 42.1 \\
\hline & Developed from external sources & 21.8 \\
\hline & Adopted from external sources & 9.6 \\
\hline & Developed in alliance with other firms & 8.6 \\
\hline & Outcome of the continuous improvements of a previous innovation & 11.2 \\
\hline \multirow[t]{3}{*}{ Type of EI adopted (\% of all EIs) } & Component addition & 14.7 \\
\hline & Change in product/process* & 42.1 \\
\hline & Considerable changes** & 31.5 \\
\hline
\end{tabular}

* Change in products/processes (partial improvement, without large changes in previous products/processes)

** Considerable changes of products/processes in order to avoid environmental damage.

Source: Own elaboration.

Table 6. Summary of the results of the EFA.

\begin{tabular}{|l|l|l|l|}
\hline RCC & $\begin{array}{l}\text { Variables } \\
\text { in the } \\
\text { initial } \\
\text { EFA }\end{array}$ & Results & Conclusion \\
\hline Physical & 5 & $\begin{array}{l}\text { Most correlations are almost null } \\
\text { and none is above 0.3. Thus, the } \\
\text { relationship between the variables } \\
\text { is very weak. Furthermore, the } \\
\text { significance of many correlations } \\
\text { exceeds the maximum error } \\
\text { allowed in this study (0.05). }\end{array}$ & $\begin{array}{l}\text { There is not an underlying structure } \\
\text { for the individual variables, i.e., these } \\
\text { the individual variables and the } \\
\text { conceptualization of the previous } \\
\text { literature provides an accurate } \\
\text { representation of the structure of }\end{array}$ \\
\hline
\end{tabular}




\begin{tabular}{|c|c|c|c|}
\hline & & & $\begin{array}{l}\text { these RCCs. Thus, these RCCs are } \\
\text { represented by } 5 \text { variables identified } \\
\text { in the literature. }\end{array}$ \\
\hline $\begin{array}{l}\text { Reputational } \\
\text { and } \\
\text { cooperational }\end{array}$ & 6 & $\begin{array}{l}\text { Two variables show relatively low } \\
\text { correlations with the rest of } \\
\text { variables and, thus, they have } \\
\text { been separated from the analysis } \\
\text { and kept individually. The KMO } \\
\text { verifies global sample adequacy. }\end{array}$ & $\begin{array}{l}\text { The results suggest that } 2 \text { factors } \\
\text { should be maintained. Two variables } \\
\text { are kept individually (proximity of } \\
\text { the firm to other cooperators and } \\
\text { importance of having suppliers } \\
\text { providing products/services } \\
\text { according to high ecological } \\
\text { standards). }\end{array}$ \\
\hline $\begin{array}{l}\text { Motivational } \\
\text { and } \\
\text { organizational }\end{array}$ & 7 & $\begin{array}{l}\text { Only two correlations are above } \\
0.3\end{array}$ & $\begin{array}{l}\text { The conceptualization of the previous } \\
\text { literature provides an accurate } \\
\text { representation of the structure of } \\
\text { these RCCs. }\end{array}$ \\
\hline Financial & 7 & $\begin{array}{l}\text { Almost all correlations are below } \\
0.3 \text {. The significance of many } \\
\text { correlations exceeds the } \\
\text { maximum error allowed in this } \\
\text { study }(0.05) \text {. }\end{array}$ & $\begin{array}{l}\text { There is not an underlying structure } \\
\text { for the individual variables. Thus, } \\
\text { those } 7 \text { variables accurately represent } \\
\text { the financial RCCs. }\end{array}$ \\
\hline $\begin{array}{l}\text { Human } \\
\text { intellectual }\end{array}$ & 4 & $\begin{array}{l}\text { One variable presents very low } \\
\text { correlations with the rest. It is } \\
\text { separated from the analysis and } \\
\text { kept individually. The EFA } \\
\text { suggests that one factor should be } \\
\text { maintained. Another factor would } \\
\text { pick up the variable "degree of } \\
\text { formalization of the management } \\
\text { of knowledge in the firm". }\end{array}$ & $\begin{array}{l}\text { Two factors have been kept in the } \\
\text { definitive analysis. The variable } \\
\text { "amount of budget dedicated to } \\
\text { training" has been kept apart. }\end{array}$ \\
\hline Technological & 2 & $\begin{array}{l}\text { Most surveyed firms have } \\
\text { registered at least one patent. } \\
\text { There is evidence of technological } \\
\text { trajectories for } 24 \% \text { of firms. }\end{array}$ & $\begin{array}{l}\text { These RCCs are proxied by the } \\
\text { existence of patents. }\end{array}$ \\
\hline
\end{tabular}

Source: Own elaboration. 
Table 7. Results of the parameter estimation for each EI type compared to the reference

EI.

\begin{tabular}{|c|c|c|c|c|c|c|c|c|}
\hline & \multicolumn{2}{|c|}{ 1.Systemic } & \multicolumn{2}{|c|}{ 2. Externally driven } & \multicolumn{2}{|c|}{$\begin{array}{l}\text { 4. Radical and } \\
\text { technology-push }\end{array}$} & \multicolumn{2}{|c|}{ 5. Eco-efficient } \\
\hline & Sig. & $\operatorname{Exp}(\mathbf{B})$ & Sig. & $\operatorname{Exp}(B)$ & Sig. & $\operatorname{Exp}(B)$ & Sig. & $\operatorname{Exp}(B)$ \\
\hline \multicolumn{9}{|c|}{ PHYSICAL RCCs } \\
\hline $\begin{array}{l}\text { Perceived slack of physical } \\
\text { RCCs }\end{array}$ &, $017^{* *}$ & 11,015 & ,997 & 230,732 &, $026^{* *}$ & 8,069 &, $012 * *$ & 11,317 \\
\hline $\begin{array}{l}\text { Degree of use of physical } \\
\text { resources }\end{array}$ & ,936 & ,998 & ,994 & ,674 &, 540 & ,982 &, 779 & ,992 \\
\hline Flexibility of physical RCCs & ,516 & 1,280 & ,996 & 117,848 & ,777 & 1,103 & ,688 & 1,146 \\
\hline $\begin{array}{l}\text { Degree of novelty of physical } \\
\text { RCCs }\end{array}$ & , 186 & 3,935 & ,994 & 17299,634 &, $031 * *$ & 7,396 & ,314 & 2,402 \\
\hline Existence of physical RCCs &, $034 * *$ & 1,026 & ,999 & ,973 &, $006 * * *$ & 1,032 & ,517 & 1,007 \\
\hline \multicolumn{9}{|c|}{ REPUTATIONAL AND COOPERATIONAL RCCs } \\
\hline Cooperation RCCs &, $000^{* * *}$ & ,012 & ,981 & $4,803 \mathrm{E}+14$ &, $014 * *$ & ,139 & ,365 & ,493 \\
\hline Reputation RCCs & ,608 & 1,390 & ,997 & 116,151 & ,370 & 1,678 & 227 & 1,818 \\
\hline Eco-innovative "clusters" & 537 & 1,569 & 989 & $6,786 \mathrm{E}-05$ & ,890 & ,909 & ,357 & 1,817 \\
\hline $\begin{array}{l}\text { Sustainable supply } \\
\text { chains/networks }\end{array}$ &, $057^{*}$ & 7,372 & ,994 & $1,472 \mathrm{E}-06$ &, $033 * *$ & 8,472 &, $080 *$ & 5,519 \\
\hline \multicolumn{9}{|c|}{ MOTIVATIONAL AND ORGANIZATIONAL RCCs } \\
\hline $\begin{array}{l}\text { Orientation of corporate } \\
\text { culture towards sustainability }\end{array}$ &, $008^{* *}$ & 19,635 & ,995 & $8,634 \mathrm{E}-05$ &, $047 * *$ & 8,504 & , 194 & 3,768 \\
\hline $\begin{array}{l}\text { Future orientation of the main } \\
\text { corporate goals }\end{array}$ & , 144 &, 271 & ,993 & $8,211 \mathrm{E}-05$ &, 106 & ,253 &, $044 * *$ & , 177 \\
\hline Main motivation: technology &, $000 * * *$ & $\begin{array}{r}3,371 \mathrm{E}- \\
05\end{array}$ & ,995 & $7,995 \mathrm{E}-27$ &, $000 * * *$ & $\begin{array}{r}9,754 \mathrm{E}- \\
05\end{array}$ & ,999 & 1539,360 \\
\hline Main motivation: market &, $001 * * *$ &, 000 & ,996 & $7,280 \mathrm{E}-24$ &, $000 * * *$ & ,001 & ,999 & 73674,823 \\
\hline $\begin{array}{l}\text { Main motivation: technology- } \\
\text { market }\end{array}$ &, $000 * * *$ & $\begin{array}{r}2,590 \mathrm{E}- \\
05\end{array}$ & ,996 & $9,944 \mathrm{E}-24$ &, $000 * * *$ &, 001 & ,999 & 3478,697 \\
\hline $\begin{array}{l}\text { Main motivation: firm-specific } \\
\text { factors }\end{array}$ &, $000^{* * *}$ & $\begin{array}{r}6,219 \mathrm{E}- \\
05\end{array}$ & ,995 & $2,763 \mathrm{E}-24$ & & 002 & ,999 & 1563,622 \\
\hline Cooperation skills (I): CRM & ,323 & ,095 & ,993 & $2,235 \mathrm{E}-10$ & ,994 & ,985 & ,183 & 21,165 \\
\hline $\begin{array}{l}\text { Cooperation skills (II): key } \\
\text { account management }\end{array}$ & ,931 & 1,192 & ,997 & 30619,998 &, 560 & 3,185 & ,275 & ,137 \\
\hline $\begin{array}{l}\text { Cooperation skills (III): } \\
\text { Frequency of client visits }\end{array}$ & ,495 &, 518 & ,984 & $2,487 \mathrm{E}+09$ & ,238 & ,336 & ,205 & ,300 \\
\hline $\begin{array}{l}\text { Ecological certification: } \\
\text { ISO14001 }\end{array}$ &, 112 &, 025 & ,998 & $4,014 \mathrm{E}-05$ &, $080^{*}$ & ,019 & ,204 & ,062 \\
\hline $\begin{array}{l}\text { Ecological certification: } \\
\text { EMAS }\end{array}$ & ,343 &, 170 & ,995 & 39666,366 & ,133 & ,082 &, $075^{*}$ & ,047 \\
\hline \multicolumn{9}{|c|}{ FINANCIAL RCCs } \\
\hline $\begin{array}{l}\text { Availability of financial } \\
\text { resources and "financial slack" }\end{array}$ &, 227 & 2,212 & ,996 & ,014 & 135 & 2,320 & ,784 & 1,164 \\
\hline
\end{tabular}




\begin{tabular}{|c|c|c|c|c|c|c|c|c|}
\hline $\begin{array}{l}\text { Ratios of "financial slack" (I): } \\
\text { Current Ratio }\end{array}$ &, 568 & 3,420 & ,996 & $8,598 \mathrm{E}-13$ &, $031 * *$ & 59,331 &, 597 & 2,546 \\
\hline $\begin{array}{l}\text { Ratios of "financial slack" (II): } \\
\text { Working Capital }\end{array}$ & ,691 & 1,000 & ,997 & 1,005 &, 861 & 1,000 & ,969 & 1,000 \\
\hline $\begin{array}{l}\text { Ratios of "financial slack" } \\
\text { (III): Gearing }\end{array}$ & ,354 & 1,221 & ,992 &, 117 &, 546 & 1,119 & ,079* & 1,520 \\
\hline Profitability of capital &, $069^{*}$ & ,910 & ,997 & ,736 & , 185 & ,937 & ,610 & 976 \\
\hline Profitability of assets & ,819 & 1,021 & ,999 & 1,094 & ,838 & ,983 & ,291 & ,914 \\
\hline Type of financing: internal & ,090* & 33,078 & ,996 & $1,416 \mathrm{E}-08$ &, $012 * *$ & 111,230 &, 152 & 12,660 \\
\hline \multicolumn{9}{|c|}{ HUMAN INTELLECTUAL RCCs } \\
\hline $\begin{array}{l}\text { Input for the creation of new } \\
\text { knowledge }\end{array}$ & ,780 & 1,233 & ,995 & 21,874 & ,658 & ,734 & ,260 & ,477 \\
\hline Formalization of knowledge & ,191 & ,382 & ,995 & ,018 & ,064* & ,282 &, $023 * *$ & ,202 \\
\hline $\begin{array}{l}\text { Amount of budget dedicated to } \\
\text { training }\end{array}$ & ,803 & ,863 & ,999 &, 161 &, 826 & ,886 & ,668 & 1,262 \\
\hline \multicolumn{9}{|c|}{ TECHNOLOGICAL RCCs } \\
\hline Patents & ,342 & 237 & 994 & $1,263 \mathrm{E}+06$ &, $007 * *$ & ,021 & ,301 & 2,281 \\
\hline
\end{tabular}

Source: Own elaboration.

Table 8. Summary of RCCs as drivers or barriers for different EI types (compared to the reference $\mathbf{E I})$.

\begin{tabular}{|c|c|c|c|c|}
\hline Drivers/barriers & 1.Systemic EIs & $\begin{array}{l}\text { 2. Externally driven } \\
\text { EIs }\end{array}$ & $\begin{array}{l}\text { 4. Radical and tech- } \\
\text { push EIs }\end{array}$ & 5. Eco-efficient EIs \\
\hline \multicolumn{5}{|c|}{ PHYSICAL RCCs } \\
\hline $\begin{array}{l}\text { Perceived slack of } \\
\text { physical RCCs }\end{array}$ & Driver & & Driver & Driver \\
\hline $\begin{array}{l}\text { Degree of novelty of } \\
\text { RCCs }\end{array}$ & & & Driver & \\
\hline $\begin{array}{l}\text { Existence of physical } \\
\text { RCCs }\end{array}$ & Driver & & Driver & \\
\hline \multicolumn{5}{|c|}{ REPUTATIONAL AND COOPERATIONAL RCCs } \\
\hline Cooperation RCCs & $\begin{array}{l}\text { Barrier. Complex } \\
\text { relationship }\end{array}$ & & $\begin{array}{c}\text { Barrier. Complex } \\
\text { relationship }\end{array}$ & \\
\hline $\begin{array}{l}\text { Sustainable supply } \\
\text { chains/networks }\end{array}$ & Driver & & Driver & Driver \\
\hline \multicolumn{5}{|c|}{ MOTIVATIONAL AND ORGANIZATIONAL RCCs } \\
\hline $\begin{array}{l}\text { Orientation of } \\
\text { corporate culture } \\
\text { towards sustainability }\end{array}$ & Driver & & Driver & \\
\hline
\end{tabular}




\begin{tabular}{|c|c|c|c|c|}
\hline Drivers/barriers & 1.Systemic EIs & $\begin{array}{l}\text { 2. Externally driven } \\
\text { EIs }\end{array}$ & $\begin{array}{l}\text { 4. Radical and tech- } \\
\text { push EIs }\end{array}$ & 5. Eco-efficient EIs \\
\hline $\begin{array}{l}\text { Future orientation of } \\
\text { the main corporate } \\
\text { goals. }\end{array}$ & & & & Barrier \\
\hline $\begin{array}{l}\text { Main motivation: } \\
\text { technology }\end{array}$ & Driver & & Driver & \\
\hline $\begin{array}{l}\text { Main motivation: } \\
\text { market }\end{array}$ & Driver & & Driver & \\
\hline $\begin{array}{l}\text { Main motivation: } \\
\text { technology-market }\end{array}$ & Driver & & Driver & \\
\hline $\begin{array}{l}\text { Main motivation: } \\
\text { Firm-specific }\end{array}$ & Driver & & & \\
\hline $\begin{array}{l}\text { Certification } \\
\text { ISO14001 }\end{array}$ & & & Barrier & \\
\hline $\begin{array}{l}\text { Ecological } \\
\text { certification: EMAS }\end{array}$ & & & & Barrier \\
\hline & & FINANCIAL RCCs & & \\
\hline Current Ratio (slack) & & & Driver & \\
\hline Gearing (slack) & & & & Driver \\
\hline Profitability of capital & Barrier & & & \\
\hline $\begin{array}{l}\text { Type of financing: } \\
\text { internal. }\end{array}$ & Driver & & Driver & \\
\hline \multicolumn{5}{|c|}{ HUMAN INTELLECTUAL } \\
\hline $\begin{array}{l}\text { Formalization of } \\
\text { knowledge }\end{array}$ & & & Barrier. & $\begin{array}{c}\text { Barrier. Complex } \\
\text { relationship }\end{array}$ \\
\hline \multicolumn{5}{|c|}{ TECHNOLOGICAL RCCs } \\
\hline Patents & & & Barrier & \\
\hline
\end{tabular}

Source: Own elaboration. 